\title{
Funneliformis mosseae Improves Growth and Nutrient Accumulation in Wheat by Facilitating Soil Nutrient Uptake under Elevated $\mathrm{CO}_{2}$ at Daytime, Not Nighttime
}

\author{
Songmei Shi ${ }^{1,2,+}$, Xie Luo ${ }^{1,2,+}$, Miao Wen ${ }^{1,2}$, Xingshui Dong ${ }^{1,2} \mathbb{D}$, Sharifullah Sharifi ${ }^{1,2}$, Deti Xie , $^{1,2}$ \\ and Xinhua $\mathrm{He}^{1,2,3,4, *(D)}$
}

Citation: Shi, S.; Luo, X.; Wen, M.; Dong, X.; Sharifi, S.; Xie, D.; He, X.

Funneliformis mosseae Improves Growth and Nutrient Accumulation in Wheat by Facilitating Soil Nutrient Uptake under Elevated $\mathrm{CO}_{2}$ at Daytime, Not Nighttime. J. Fungi 2021, 7, 458. https://doi.org/ 10.3390/jof7060458

Academic Editor: Raffaella Maria Balestrini

Received: 9 May 2021

Accepted: 6 June 2021

Published: 7 June 2021

Publisher's Note: MDPI stays neutral with regard to jurisdictional claims in published maps and institutional affiliations.

Copyright: (c) 2021 by the authors. Licensee MDPI, Basel, Switzerland. This article is an open access article distributed under the terms and conditions of the Creative Commons Attribution (CC BY) license (https:// creativecommons.org/licenses/by/ $4.0 /)$
1 Centre of Excellence for Soil Biology, College of Resources and Environment, and Chongqing Key Laboratory of Plant Resource Conservation and Germplasm Innovation, School of Life Sciences, Southwest University, Chongqing 400716, China; shismei@email.swu.edu.cn (S.S.); luox123@email.swu.edu.cn (X.L.); wenmiao77@163.com (M.W.); xingshuid@outlook.com (X.D.); nsharifullah@gmail.com (S.S.); xdt@swu.edu.cn (D.X.)

2 National Base of International S\&T Collaboration on Water Environmental Monitoring and Simulation in Three Gorges Reservoir Region, Chongqing 400716, China

3 Department of Land, Air and Water Resources, University of California at Davis, Davis, CA 95616, USA

4 School of Biological Sciences, University of Western Australia, Perth, WA 6009, Australia

* Correspondence: xinhua.he@uwa.edu.au; Tel.: +86-187-2328-9058

+ These authors contributed equally to this work.

Abstract: The concurrent effect of elevated $\mathrm{CO}_{2}\left(\mathrm{eCO}_{2}\right)$ concentrations and arbuscular mycorrhizal fungi (AMF) on plant growth, carbon $(\mathrm{C})$, nitrogen $(\mathrm{N})$, phosphorus $(\mathrm{P})$ and potassium $(\mathrm{K})$ accumulations in plant and soil is largely unknown. To understand the mechanisms of $\mathrm{eCO}_{2}$ and mycorrhization on wheat (Triticum aestivum) performance and soil fertility, wheat seedlings were grown under four different $\mathrm{CO}_{2}$ environments for 12 weeks, including (1) ambient $\mathrm{CO}_{2}\left(\mathrm{ACO}_{2}\right.$, 410/460 ppm, daytime/nighttime), (2) sole daytime $\mathrm{eCO}_{2}\left(\mathrm{DeCO}_{2}, 550 / 460 \mathrm{ppm}\right)$, (3) sole nighttime $\mathrm{eCO}_{2}\left(\mathrm{NeCO}_{2}, 410 / 610 \mathrm{ppm}\right)$, and (4) dual or continuous daytime/nighttime $\mathrm{eCO}_{2}\left((\mathrm{D}+\mathrm{N}) \mathrm{eCO}_{2}\right.$, $550 / 610 \mathrm{ppm}$ ), and with or without AMF (Funneliformis mosseae) colonization. $\mathrm{DeCO}_{2}, \mathrm{NeCO}_{2}$ and (D $+\mathrm{N}) \mathrm{eCO}_{2}$ generally significantly increased shoot and root biomass, plant $\mathrm{C}, \mathrm{N}, \mathrm{P}$ and $\mathrm{K}$ accumulation, soil invertase and urease activity, but decreased shoot and root N, P and $\mathrm{K}$ concentrations, and soil available $\mathrm{N}, \mathrm{P}$ and $\mathrm{K}$. Compared with non-AMF, AMF effects on above-mentioned characteristics were significantly positive under $\mathrm{ACO}_{2}, \mathrm{DeCO}_{2}$ and $(\mathrm{D}+\mathrm{N}) \mathrm{eCO}_{2}$, but negative on plant biomass, $\mathrm{C}, \mathrm{N}, \mathrm{P}$ and $\mathrm{K}$ accumulation under $\mathrm{NeCO}_{2}$. Overall, AMF colonization alleviated soil nutrient constraints on plant responses to $\mathrm{DeCO}_{2}$, while $\mathrm{NeCO}_{2}$ decreased $\mathrm{AMF}^{\prime}$ s beneficial effects on plants. These results demonstrated that an integration of $\mathrm{AMF}^{\prime}$ s benefits to plants under factual field $\mathrm{DeCO}_{2}$ and/or $\mathrm{NeCO}_{2}$ will be critical for managing the long-term consequence of future $\mathrm{CO}_{2}$ rising on global cropping systems.

Keywords: arbuscular mycorrhiza; biomass production; enzyme activity; nitrogen; phosphorus; potassium

\section{Introduction}

An increase in atmospheric carbon dioxide $\left(\mathrm{ACO}_{2}\right)$ concentration is one of the most important environmental factors reflecting global climate change [1]. The $\mathrm{ACO}_{2}$ concentration has been increased from 280 ppm during the industrial revolution to $419.64 \mathrm{ppm}$ (https: / / www.co2.earth Accessed on 5 June 2021), and could reach 550 ppm in the next 50 years [1]. Elevated $\mathrm{CO}_{2}\left(\mathrm{eCO}_{2}\right)$ directly influences soil-plant systems via improving plant growth [2-4]. Elevated $\mathrm{CO}_{2}$ generally exhibits 'fertilization effects' due to stimulation of photosynthesis and biomass accumulation in various $C_{3}$ crops, including wheat (Triticum aestivum L.) [5-7]. Increased productivity of crops needs a large supply of nutrients (especially nitrogen, $\mathrm{N}$; phosphorous, $\mathrm{P}$; and potassium, $\mathrm{K}$; etc.) to match their increased carbon 
(C) assimilation under $\mathrm{eCO}_{2}$ [8-11]. Soil nutrient availability was indeed decreased over a long-term $\mathrm{eCO}_{2}$ owing to an increased nutrient demand by $\mathrm{eCO}_{2}$-stimulated growth [12]. The e $\mathrm{CO}_{2}$ effects were often gradually diminished when plants grew under nutrient-limited soils $[13,14]$. Furthermore, the beneficial effect of $\mathrm{eCO}_{2}$ on biomass production can lead to changes in C, N, P, K, and other nutrient content in both plants and soils [15-18]. These changes affected agricultural ecosystem processes, including nutrient cycling [8], soil organic matter decomposition [19], and microbial processes [20,21]. Soil enzymes, which integrate information from soil microbial and biochemical statuses, could serve as indicators of various changes in the plant-soil system [22]. Thus, soil enzyme activities are also likely to change under $\mathrm{eCO}_{2}[3,23]$. It would be worthy to understand the response of aboveground biomass and the feedback of belowground components (especially soil nutrients, soil microorganisms and enzyme activities) to $\mathrm{eCO}_{2}$.

Arbuscular mycorrhizal fungi (AMF) can form mutualistic associations with the roots of $>80 \%$ of vascular plant species and improve plant nutrient uptake [24]. AMF are important in defining plant responses to $\mathrm{eCO}_{2}[4,25-28]$. Elevated $\mathrm{CO}_{2}$ at daytime or continuously from daytime to nighttime has a positive effect on $\mathrm{C}_{3}$ crops' photosynthetic $\mathrm{C}$ assimilation, which increases the belowground transportation of photosynthates to support AMF symbiosis [29,30]. In turn, AMF help to alleviate the increased plant nutrient limitation associated with increased photosynthetic rates under daytime or continuous $\mathrm{eCO}_{2}[27,30,31]$. The costs and benefits to plants and AMF are a function of the balance between the $\mathrm{C}$ cost of fungi and nutrient supply to the plant. On the one hand, $\mathrm{eCO}_{2}$ usually decreases $\mathrm{N}, \mathrm{P}$, and $\mathrm{K}$ concentrations in plant tissues $[15,17,32]$, such as a decrease of $27 \%$ for $\mathrm{N}, 34 \%$ for $\mathrm{P}$, and $20 \%$ for $\mathrm{K}$ in wheat grains [33], and $29 \%$ for $\mathrm{N}$ in wheat flag leaves [34]. On the other hand, $\mathrm{eCO}_{2}$ improves plant $\mathrm{N}, \mathrm{P}$, and $\mathrm{K}$ acquisition when plants associate with AMF $[4,26,35,36]$, which help to alleviate N-, P-, or K-limitation [10]. However, the effects of mycorrhizal association are not always positive under $\mathrm{eCO}_{2}$ when the $\mathrm{C}$ costs of AMF outweigh their benefits to plant nutrient uptake [37]. For instance, $\mathrm{N}$ availability to flag leaves of the Rhizophagus intraradices colonized durum wheat was lower under $700 \mathrm{ppm} \mathrm{eCO}$ than under 400 ppm $\mathrm{CO}_{2}$ [34]. The mechanisms for AMF on plant performance under daytime $\mathrm{eCO}_{2}$ thus remain largely unknown, let alone under nighttime $\mathrm{eCO}_{2}$.

In fact, the atmospheric $\mathrm{CO}_{2}$ concentration at plant height is usually higher during nighttime than during daytime [38], considering the corresponding $\mathrm{CO}_{2}$ variation or fluctuation with plant photosynthesis and soil respiration, particularly in agricultural fields. The average atmospheric $\mathrm{CO}_{2}$ in Australia, Japan and the USA varied from $390 \mathrm{ppm}$ during daytime to $465 \mathrm{ppm}$ during nighttime [38]. Indeed, a three-year (2017-2019) period of our field observation recorded that the average daily atmospheric $\mathrm{CO}_{2}$ ranged from $417 \pm 16 \mathrm{ppm}$ at daytime and $463 \pm 27 \mathrm{ppm}$ at nighttime at the National Monitoring Base for Purple Soil Fertility and Fertilizer Efficiency close to the campus of Southwest University, Chongqing, China (see Figure S1 from October 2017 to March 2018). As a consequence, plants should differentially respond to such contrasting daytime or nighttime atmosphere $\mathrm{CO}_{2}$ concentrations [39]. Thus variations in daytime and/or nighttime atmosphere $\mathrm{CO}_{2}$ concentrations shall provide a closer simulation of currently atmospheric $\mathrm{CO}_{2}$ conditions that plants will respond to in the near future. However, owing to the likely extra cost and maintenance of $\mathrm{CO}_{2}$ gas supply, only a few studies have examined the different responses of plant growth and yield between contrasting daytime and nighttime $\mathrm{eCO}_{2}$ concentrations [40-44]. For instance, it was daytime, not nighttime $\mathrm{eCO}_{2}$, that improved Morus alba growth [39]. The biomass production in Amaranthus retroflexus and Zea mays was significantly reduced under $700 \mathrm{ppm}$ nighttime $\mathrm{eCO}_{2}$ than under $370 \mathrm{ppm}$ nighttime $\mathrm{eCO}_{2}$ [45], although such nighttime $\mathrm{eCO}_{2}$ effects on plant growth were plant speciesspecific [46]. The contrasting positive or negative effects of nighttime $\mathrm{eCO}_{2}$ on plant growth would result from dark respiration $[47,48]$. It is suggested that dark respiration was decreased by $20-45 \%$ under $700-1000 \mathrm{ppm} \mathrm{eCO}$ at nighttime in the short-term $[41,43,49]$. In contrast, dark respiration usually, but not always, increased in the long-term such $\mathrm{CO}_{2}$ 
nighttime enrichments $[47,50]$. Mechanisms of $\mathrm{eCO}_{2}$ at nighttime that may affect plant growth and $\mathrm{C}$ assimilation have not been established yet. Questions hence arise as to whether the plant nutrient demand could be increased under $\mathrm{eCO}_{2}$ at nighttime, and whether AMF symbiosis could play the same role in $\mathrm{C}$ and nutrient balance under $\mathrm{eCO}_{2}$ at daytime or nighttime. Such information is essential for understanding the mechanisms affecting $\mathrm{C}$ and $\mathrm{N}$ dynamics under future $\mathrm{CO}_{2}$-increasing scenarios.

We therefore designed an environment-controlled system, which has minimal impact on light, air temperature and humidity, while providing either on-site ambient or elevated $\mathrm{CO}_{2}$ concentrations for growing plants during daytime and/or nighttime. The objectives of the present study were to address: (1) How auto-controlled field daytime and/or nighttime $\mathrm{eCO}_{2}$ could affect plant biomass production, and $\mathrm{C}, \mathrm{N}$, and $\mathrm{P}$ uptake or accumulation; (2) whether AMF effects on soil nutrient uptake could alleviate nutrient constraints on responses to $\mathrm{eCO}_{2}$ at both daytime and nighttime; and (3) whether the interactive effects of $\mathrm{eCO}_{2}$ and AMF on plant performance and related soil properties could be differentiated between daytime and nighttime $\mathrm{eCO}_{2}$. In doing so, winter wheat (T. aestivum cv. Yunmai) inoculated with or without AMF was grown in soil (Eutric Regosol, FAO Soil classification system) filled pots inside environmentally controlled glass-made chambers, which had similar growth conditions except different $\mathrm{CO}_{2}$ concentrations at daytime and/or nighttime. Plant performance and soil properties were then compared 12 weeks after sowing.

\section{Materials and Methods}

\subsection{Experiment Design and Treatments}

In a completed random arrangement, the experiment was a split plot design with atmospheric $\mathrm{CO}_{2}$ concentrations as the main factor and mycorrhizal inoculation as the subfactor, and involved two AMF treatments: inoculated with Funneliformis mosseae and autoclaved $F$. mosseae (non-AMF) and four atmospheric $\mathrm{CO}_{2}$ concentration treatments (Figure 1). Based on the on-site daily observations of $417 \pm 16 / 463 \pm 27 \mathrm{ppm}$ (daytime/nighttime) between October 2017 and March 2018 (see Figure S1A,B) and an estimated 550 ppm in the next 50 years [1], four different day and / or night $\mathrm{CO}_{2}$ concentrations $( \pm 30 \mathrm{ppm})$ or treatments were applied: (1) ambient $\mathrm{CO}_{2}\left(\mathrm{ACO}_{2}, 410 \mathrm{ppm}\right.$ daytime $/ 460 \mathrm{ppm}$ nighttime), (2) daytime $\mathrm{eCO}_{2}$ only $\left(\mathrm{DeCO}_{2}, 550 / 460 \mathrm{ppm}\right)$, (3) nighttime $\mathrm{eCO}_{2}$ only $\left(\mathrm{NeCO}_{2}, 410 / 610 \mathrm{ppm}\right)$, and (4) continuous daytime and nighttime $\mathrm{eCO}_{2}\left[(\mathrm{D}+\mathrm{N}) \mathrm{eCO}_{2}, 550 / 610 \mathrm{ppm}\right]$. The respective daytime and nighttime e $\mathrm{eO}_{2}$ concentrations were thus increased by $\sim 33.33 \%$ of the $\mathrm{ACO}_{2}$ treatment. Daytime was from 07:00 a.m. to 19:00 p.m. and nighttime was from 19:00 p.m. to $07: 00$ a.m. Each $\mathrm{CO}_{2}$ treatment owned three chambers for a total of 12 chambers to the four $\mathrm{CO}_{2}$ treatments in a completely randomized experimental arrangement within three blocks (Figure S2A). The arrangement of chambers was crisscrossed with $4 \mathrm{~m}$ apart from each other to avoid the sunshade of chambers.

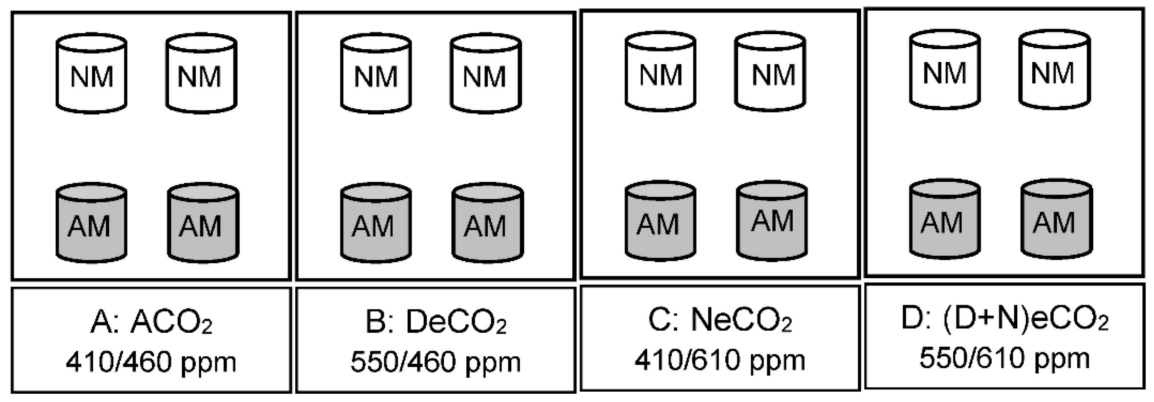

Figure 1. A schematic diagram showing the experiment designs. NM: non-AMF; AM: inoculated AMF. (A): $\mathrm{ACO}_{2}$, ambient $\mathrm{CO}_{2} ;(\mathbf{B})$ : DeCO 2 , elevated $\mathrm{CO}_{2}$ concentrations at daytime; (C). $\mathrm{NeCO}_{2}$, elevated $\mathrm{CO}_{2}$ concentrations at nighttime; and (D): $(\mathrm{D}+\mathrm{N}) \mathrm{eCO}$, elevated $\mathrm{CO}_{2}$ concentrations at both daytime and nighttime. 


\subsection{Experimental Facility}

This study was conducted from 9 November 2017 and 2 February 2018 in a $\mathrm{CO}_{2}$ exposure facility at the National Monitoring Base for Purple Soil Fertility and Fertilizer Efficiency $\left(29^{\circ} 48^{\prime} \mathrm{N}, 106^{\circ} 24^{\prime} \mathrm{E}, 266.3 \mathrm{~m}\right.$ above sea level) on the campus of Southwest University, Chongqing, China. The $\mathrm{CO}_{2}$ auto-controlling facility (DSS-QZD, Qingdao Shengsen Institute of CNC Technology, Shandong, China) consists of a control system and 12 environmentally controlled chambers (Figure $\mathrm{S} 2 \mathrm{~A}$ ), and the $\mathrm{CO}_{2}$ is supplied by $\mathrm{CO}_{2}$ cylinders (Figure $\mathrm{S} 2 \mathrm{~F}$ ). The $\mathrm{CO}_{2}$ cylinders with electric point pressure meters are connected to a $\mathrm{CO}_{2}$ control system to maintain $\mathrm{CO}_{2}$ gas flow into each chamber with the targeted $\mathrm{CO}_{2}$ concentration (Figure S2E).

Each growth chamber had a rectangular floor base, supported by a steel frame hanging $50 \mathrm{~cm}$ above the cement ground base (Figure S2A). The bottom floors of the growth chamber are made up of polyvinyl chloride plates, and the four-sided walls and top roofs of the chamber are constructed by tempered glass $(10 \mathrm{~mm}$ thickness, $90 \%$ light transmission rate, Yutao Glass Company, Jiulongpo, Chongqing, China) (Figure S2A). The growth chamber has a size of $1.5 \mathrm{~m} \times 1.0 \mathrm{~m} \times 2.5 \mathrm{~m}$ (length $\times$ width $\times$ height) in order to grow maize, Sorghum bicolor, Glycine max, wheat, and so forth. The electron sensors for monitoring humidity, temperature, light intensity, and $\mathrm{CO}_{2}$ concentrations are mounted on the outer and inner surfaces of the glass wall in each chamber to monitor their variations (Figure S2B-D). The air humidity, temperature, and $\mathrm{CO}_{2}$ concentrations are automatically controlled by their respective electronic bits and pieces (Figure S2G). The monitor's signals are fed into proportionally integrated differential controllers that regulate the opening time within a $10 \mathrm{~s}$ cycle (Figure S2B,C,G). This automatic electronic controlling system can automatically regulate and instantly visualize the fluctuation of $\pm 30 \mathrm{ppm} \mathrm{CO}_{2}$ concentration, $\pm 0.5^{\circ} \mathrm{C}$ air temperature and $\pm 5 \%$ humidity inside and outside the chamber (Figure 2 and Figure S2B,C). The targeted $\mathrm{CO}_{2}$ concentration inside is maintained by injecting $99.99 \% \mathrm{CO}_{2}$ from the cylinder (Figure $\mathrm{S} 2 \mathrm{E}, \mathrm{F}$ ) using a solenoid valve controlled by a mini-computer (Figure S2G). When the $\mathrm{CO}_{2}$ concentration inside a chamber exceeds the targeted concentration, the inside air is pumped out using a pump controlled by the mini-computer and filtered with $1.0 \mathrm{M} \mathrm{NaOH}$ solution. When the humidity inside a chamber is higher than that of outside the air humidity, the inside air is pumped out using another pump controlled by the mini-computer and filtered with solid anhydrous calcium chloride. The temperature is automatically maintained at $0.5^{\circ} \mathrm{C}$ variation between inside and outside the chamber using an air conditioner (Gree, Zhuhai Gree Corp., Zhuhai, China) controlled by the mini-computer.

\subsection{Mycorrhizal Inoculum, Growth Soil and Plant Growth Conditions}

The inoculum of AMF (Funneliformis mosseae) was purchased from the Bank of Glomales at the Institute of Plant Nutrition and Resources, Beijing Academy of Agriculture and Forestry, Beijing, China. The inoculum was a mixture of soil (50 spores per gram dry soil), mycorrhizal mycelia and root segments. The growth soil (Eutric Regosol, FAO Soil Classification System, developed from Jurassic purple shale and sandstone) was air-dried, sieved by passing through a $2 \mathrm{~mm}$ mesh and sterilized at $121{ }^{\circ} \mathrm{C}$ for $120 \mathrm{~min}$. The pots (height $/$ diameter $=21 / 17 \mathrm{~cm}$ ) were then filled with $3.4 \mathrm{~kg}$ of sterilized soil. The soil $(\mathrm{pH}$ 6.8) had $10.56 \mathrm{~g}$ of organic carbon $\mathrm{kg}^{-1}, 0.66 \mathrm{~g}$ total $\mathrm{N} \mathrm{kg}^{-1}, 0.61 \mathrm{~g}$ total $\mathrm{P} \mathrm{kg}^{-1}, 97 \mathrm{mg}$ available $\mathrm{N} \mathrm{kg}^{-1}, 17 \mathrm{mg}$ available $\mathrm{P} \mathrm{kg} \mathrm{kg}^{-1}$ and $197 \mathrm{mg}$ available $\mathrm{K} \mathrm{kg}^{-1}$.

Seeds of winter wheat (T. aestivum cv. Yunmai) were surface-sterilized with $10 \% \mathrm{H}_{2} \mathrm{O}_{2}$ for $20 \mathrm{~min}$, thoroughly rinsed with sterile water, and then pre-germinated on sterilized moist filter paper at $25 / 20^{\circ} \mathrm{C}$ (day/night) for $36 \mathrm{~h}$. Eight germinating wheat seeds were sown in one plastic pot. A total of $20 \mathrm{~g}$ of $F$. mosseae inocula were put at a $5 \mathrm{~cm}$ soil surface depth inside each pot, while an equal amount of autoclaved $\left(121^{\circ} \mathrm{C}, 0.1 \mathrm{Mpa}, 120 \mathrm{~min}\right)$ inoculum was supplied to the non-mycorrhizal pots. A volume of $5.0 \mathrm{~mL}$ filtrate $(0.45 \mu \mathrm{m}$ syringe filter, Millipore Corporation, Billerica, MA, USA) from the F. mosseae inoculum was added to each non-mycorrhizal pot to minimize differences in other microbial communities. 
Then, two mycorrhizal pots and two non-mycorrhizal pots were placed into each growth chamber, and thus, the three replicated chambers had a total of six replicated pots for each $\mathrm{CO}_{2}$ concentration treatment. Except the $\mathrm{CO}_{2}$ concentration, the chambers had similar other growth conditions, such as light, air temperature and humidity, as monitored by the abovementioned auto-controlling facility (Figure 2). To minimize differences in growth conditions, the positions of growth pots in each chamber were rotated once a week, and shifted to another replicate chamber once fortnightly. In addition, all the pots with plants were watered once with Hoagland solution to a total of $100 \mathrm{mg} \mathrm{N}, 50 \mathrm{mg} \mathrm{P}$ and $75 \mathrm{mg} \mathrm{K}$ per pot and the soil moisture during the whole growth period was maintained at $70 \%$ water-holding capacity with sterilized water by routing weighing of pots once every two days.
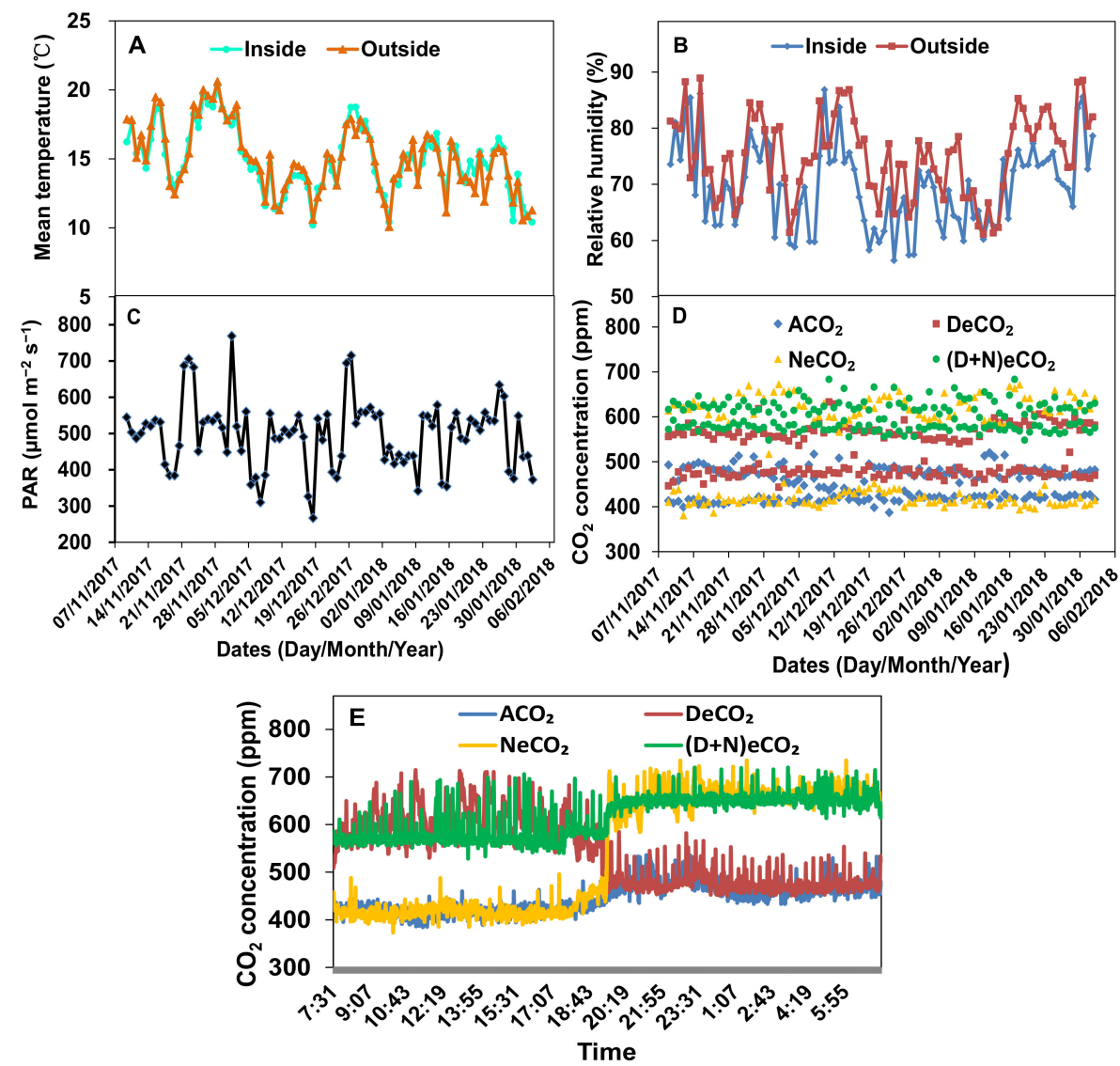

Figure 2. Mean temperature (A), relative humidity (B), photosynthetic active radiation (PAR, $(\mathrm{C})$ ) and $\mathrm{CO}_{2}$ concentration $(\mathbf{D}, \mathbf{E})$ over the experimental period in the growth chambers. $\mathrm{ACO}_{2}$ : ambient $\mathrm{CO}_{2}, \mathrm{DeCO}$ : elevated $\mathrm{CO}_{2}$ concentrations at daytime, $\mathrm{NeCO}_{2}$ : elevated $\mathrm{CO}_{2}$ concentrations at nighttime, $(\mathrm{D}+\mathrm{N}) \mathrm{eCO}_{2}$ : elevated $\mathrm{CO}_{2}$ concentrations at both daytime and nighttime.

\subsection{Harvest, Sampling and Analyses}

Plant and soil samples were harvested 12 weeks after sowing during the jointing stage and were combined from the two pots in each chamber as a composite sample. Plant tissues were divided into shoots (leaves and stems) and roots. Plant fresh roots were carefully washed with tap water and rinsed with deionized water. A portion of fresh roots was stored in 50\% ethanol to determine root AMF colonization. The remaining fresh roots and shoots were dried at $105^{\circ} \mathrm{C}$ for $30 \mathrm{~min}$ and then at $75^{\circ} \mathrm{C}$ for $>48 \mathrm{~h}$ until they reached a consistent dry weight. Soil samples, collected from soils that had been well-mixed from each growth pot, were divided into two parts after the removal of debris and fine roots. The first part of the soil was air-dried for $>48 \mathrm{~h}$ for the determination of chemical properties, and the second part was immediately transferred to the laboratory and stored at $-20{ }^{\circ} \mathrm{C}$ for the determination of enzyme activities. 


\subsection{Determination of AMF Colonization}

The percentage of root AMF colonization was measured according to Brundrett et al. [51]. The roots were cut into $1.0 \mathrm{~cm}$ segments and cleared with $10 \%(w / v) \mathrm{KOH}$ in a water bath at $90{ }^{\circ} \mathrm{C}$ for $20 \mathrm{~min}$, rinsed in water. The cleared root segments were acidified in $0.2 \mathrm{M} \mathrm{HCl}$ for $3 \mathrm{~min}$ and then stained with $0.05 \%$ trypan blue. The stained segments were mounted on glass slides, and a total of 50 randomly selected root segments from each replicate were examined under a microscope. The ratio of the number of root segments that showed a fungal structure (spores, hyphae, arbuscules or vesicles) and the total number of root segments was calculated as the percentage of root AMF colonization.

\subsection{Determination of $C, N, P$ and $K$ in Plants and Soils}

The oven-dried shoot and root and air-dried soil samples were ground to fine powder for soil and plant $\mathrm{C}, \mathrm{N}, \mathrm{P}$ and $\mathrm{K}$ analyses. Plant $\mathrm{C}$ concentration was determined using the potassium dichromate-sulfuric acid oxidation method [52]. After digestion with $98 \%$ sulfuric acid and 30\% hydrogen peroxide, plant N, P, and K concentrations were determined with the Kjeldahl method, the vanadium molybdate yellow colorimetric method, and flame photometry, respectively [52]. Soil available $\mathrm{N}$ (AN) was measured by the micro-diffusion technique after alkaline hydrolysis [52]. Soil available P (AP) was extracted with $0.5 \mathrm{M}$ $\mathrm{NaHCO}_{3}$ and then measured by the Mo-Sb anti spectrophotometric method [52]. Soil available $\mathrm{K}(\mathrm{AK})$ was extracted with $1.0 \mathrm{M}$ ammonium acetate and then determined by flame photometry [52].

\subsection{Determination of Soil Enzyme Activity}

Soil invertase activity (mg glucose $\mathrm{g}^{-1}$ soil $^{-1}$ ) was determined firstly by incubating five grams of fresh soil with $1 \mathrm{~mL}$ toluene, $15 \mathrm{~mL} \%(w / v)$ sucrose, and $5 \mathrm{~mL}$ phosphate buffer (pH 5.5) for $24 \mathrm{~h}$ at $37^{\circ} \mathrm{C}$. After incubation, $1 \mathrm{~mL}$ filtrate with $3 \mathrm{~mL}$ 3,5-dinitrosalicylic acid were then incubated in boiling water for $5 \mathrm{~min}$. Subsequently, the reaction solution was diluted to $50 \mathrm{~mL}$ with distilled water and spectrophotometrically measured at $508 \mathrm{~nm}$ [53].

Soil urease activity $\left(\mathrm{mg} \mathrm{NH}_{4}{ }^{+}-\mathrm{N} \mathrm{g}^{-1}\right.$ soil h$\left.{ }^{-1}\right)$ was determined firstly by incubating five grams of fresh soil with $1 \mathrm{~mL}$ toluene, $10 \mathrm{~mL} \mathrm{10 \%} \mathrm{urea} \mathrm{solution}(w / v)$, and $20 \mathrm{~mL}$ citrate buffer ( $\mathrm{pH}$ 6.7) for $24 \mathrm{~h}$ at $37^{\circ} \mathrm{C}$. After incubation, $2 \mathrm{~mL}$ filtrates were mixed with $4 \mathrm{~mL}$ sodium phenol solution and $3 \mathrm{~mL} 0.9 \%(v / v)$ sodium hypochlorite solution in a $50 \mathrm{~mL}$ volumetric flask. After $20 \mathrm{~min}$, the reaction solution was then diluted to $50 \mathrm{~mL}$ with distilled water and spectrophotometrically measured at $578 \mathrm{~nm}$ [53].

Neutral phosphatase activity (mg phenol g ${ }^{-1} \mathrm{~h}^{-1}$ ) was determined firstly by incubating five grams of fresh soil, $1 \mathrm{~mL}$ toluene and $5 \mathrm{~mL}$ disodium phenyl phosphate solution and $5 \mathrm{~mL}$ citrate buffer ( $\mathrm{pH} 7.0$ ) for $24 \mathrm{~h}$ at $37^{\circ} \mathrm{C}$. After incubation, $1 \mathrm{~mL}$ filtrate with $5 \mathrm{~mL}$ borate buffer $(\mathrm{pH} 9.0), 3 \mathrm{~mL} 2.5 \%$ potassium ferrocyanide $(w / v)$ and $3 \mathrm{~mL} 0.5 \%$-aminoantipyrine $(w / v)$ were then thoroughly mixed in a $50 \mathrm{~mL}$ volumetric flask. Subsequently, the reaction solution was diluted to $50 \mathrm{~mL}$ with distilled water and spectrophotometrically measured at $570 \mathrm{~nm}$ [54].

\subsection{Statistical Analysis}

Statistical analysis was performed using SPSS 19.0 software (SPSS Inc., Chicago, IL, USA). Data were shown as mean \pm standard error (SE). All response variable data (except for root colonization) were analyzed by two-factor analyses of variance (ANOVA). The factors in the two-way ANOVA were $\mathrm{CO}_{2}$ level and arbuscular mycorrhiza. Significant differences among treatments were compared by Tukey's Multiple Range Test at $p<0.05$ using SPSS 19.0 software. Graphs were plotted using OriginPro2018 software (OriginLab Corp., Northampton, MA, USA).

\section{Results}

\subsection{Mycorrhizal Colonization}

A significantly greater percentage of root $\mathrm{AMF}$ colonization among $\mathrm{CO}_{2}$ treatments $(p<0.05)$ ranked in AMF plants as $(\mathrm{D}+\mathrm{N}) \mathrm{eCO}_{2}(53.60 \pm 2.25)>\mathrm{DeCO}_{2}(48.31 \pm 3.04) \approx$ 
$\mathrm{NeCO}_{2}(47.07 \pm 3.42)>\mathrm{ACO}_{2}(40.67 \pm 2.59)$, whereas no AMF colonization was detected in non-AMF plants.

\subsection{Effects of $A M F$ and $\mathrm{CO}_{2}$ on Plant $\mathrm{C}, \mathrm{N}, \mathrm{P}$ and $\mathrm{K}$ Concentration}

$\mathrm{C}$ concentrations in shoots were significantly higher under $\mathrm{eCO}_{2}$ than under $\mathrm{ACO}_{2}$ in non-AMF 12-week-old wheat seedlings, but no significant differences among $\mathrm{DeCO}_{2}$, $\mathrm{NeCO}_{2}$, and $(\mathrm{D}+\mathrm{N}) \mathrm{eCO}_{2}$. In contrast, significantly higher shoot $\mathrm{C}$ concentrations ranked in AMF plants as $(\mathrm{D}+\mathrm{N}) \mathrm{eCO} \mathrm{CO}_{2}>\mathrm{DeCO}_{2} \approx \mathrm{ACO}_{2}>\mathrm{NeCO}_{2}$. Meanwhile, only $(\mathrm{D}+\mathrm{N}) \mathrm{eCO}_{2}$ increased root $\mathrm{C}$ concentrations in both non- $\mathrm{AMF}$ and $\mathrm{AMF}$ plants. However, neither shoot $\mathrm{C}$ nor root $\mathrm{C}$ concentrations were affected by the $F$. mosseae inoculation and by $\mathrm{CO}_{2} \times \mathrm{AMF}$ interaction (Table 1).

Table 1. Carbon, nitrogen, phosphorus and potassium concentrations in shoots and roots of non-AMF and AMF-inoculated $(\mathrm{AMF})$ wheat plants grown under ambient $\mathrm{CO}_{2}\left(\mathrm{ACO}_{2}\right)$ and under-elevated $\mathrm{CO}_{2}$ concentrations at daytime $($ DeCO 2$)$, night $\left(\mathrm{NeCO}_{2}\right)$, and both daytime and nighttime $(\mathrm{D}+\mathrm{N}) \mathrm{eCO}_{2}$.

\begin{tabular}{|c|c|c|c|c|c|c|c|c|c|}
\hline \multicolumn{2}{|c|}{ Treatment } & \multicolumn{2}{|c|}{ Carbon (mg g ${ }^{-1}$ ) } & \multicolumn{2}{|c|}{ Nitrogen $\left(\mathrm{mg} \mathrm{g}^{-1}\right)$} & \multicolumn{2}{|c|}{ Phosphorus ( $\mathrm{mg} \mathrm{g}^{-1}$ ) } & \multicolumn{2}{|c|}{ Potassium (mg g ${ }^{-1}$ ) } \\
\hline Inoculation & $\mathrm{CO}_{2}$ & Shoot & Root & Shoot & Root & Shoot & Root & Shoot & Root \\
\hline \multirow{4}{*}{ Non-AMF } & $\mathrm{ACO}_{2}$ & $413 \pm 8 \mathrm{~b}, \mathrm{x}$ & $385 \pm 9 b, x$ & $37.4 \pm 1.9 \mathrm{a}, \mathrm{x}$ & $12.4 \pm 1.1 \mathrm{a}, \mathrm{y}$ & $8.39 \pm 0.20 \mathrm{a}, \mathrm{x}$ & $1.51 \pm 0.07 \mathrm{a}, \mathrm{x}$ & $31.49 \pm 0.66 \mathrm{a}, \mathrm{x}$ & $13.05 \pm 0.96 \mathrm{a}, \mathrm{y}$ \\
\hline & $\mathrm{DeCO}_{2}$ & $445 \pm 10 \mathrm{a}, \mathrm{x}$ & $403 \pm 12 b, x$ & $26.0 \pm 2.3 \mathrm{~b}, \mathrm{y}$ & $9.5 \pm 0.5 \mathrm{~b}, \mathrm{y}$ & $8.80 \pm 1.05 \mathrm{a}, \mathrm{x}$ & $0.96 \pm 0.14 \mathrm{~b}, \mathrm{y}$ & $29.66 \pm 0.81 \mathrm{~b}, \mathrm{x}$ & $8.72 \pm 1.21 \mathrm{~b}, \mathrm{x}$ \\
\hline & $\mathrm{NeCO}_{2}$ & $430 \pm 9 \mathrm{a}, \mathrm{x}$ & $393 \pm 14 b, x$ & $27.6 \pm 0.8 \mathrm{~b}, \mathrm{x}$ & $12.6 \pm 0.3 \mathrm{a}, \mathrm{x}$ & $5.15 \pm 0.84 \mathrm{~b}, \mathrm{x}$ & $1.17 \pm 0.11 \mathrm{~b}, \mathrm{x}$ & $23.60 \pm 1.82 \mathrm{~d}, \mathrm{y}$ & $8.56 \pm 1.17 b, x$ \\
\hline & $(\mathrm{D}+\mathrm{N}) \mathrm{eCO}_{2}$ & $449 \pm 13 \mathrm{a}, \mathrm{x}$ & $432 \pm 16 a, x$ & $28.3 \pm 0.8 \mathrm{~b}, \mathrm{x}$ & $14.0 \pm 1.0 \mathrm{a}, \mathrm{x}$ & $6.46 \pm 1.34 \mathrm{~b}, \mathrm{x}$ & $1.38 \pm 0.06 \mathrm{a}, \mathrm{y}$ & $27.76 \pm 0.70 c, y$ & $11.43 \pm 1.04 \mathrm{a}, \mathrm{x}$ \\
\hline \multirow{4}{*}{ AMF } & $\mathrm{ACO}_{2}$ & $432 \pm 7 \mathrm{~b}, \mathrm{x}$ & $405 \pm 15 b, x$ & $35.2 \pm 0.7 \mathrm{a}, \mathrm{x}$ & $16.8 \pm 0.9 \mathrm{a}, \mathrm{x}$ & $6.67 \pm 0.55 b, y$ & $1.47 \pm 0.13 \mathrm{~b}, \mathrm{x}$ & $31.84 \pm 0.61 \mathrm{a}, \mathrm{x}$ & $15.89 \pm 0.63 \mathrm{a}, \mathrm{x}$ \\
\hline & $\mathrm{DeCO}_{2}$ & $434 \pm 8 \mathrm{~b}, \mathrm{x}$ & $419 \pm 7 \mathrm{~b}, \mathrm{x}$ & $32.5 \pm 1.2 \mathrm{~b}, \mathrm{x}$ & $14.3 \pm 0.9 \mathrm{~b}, \mathrm{x}$ & $8.42 \pm 0.63 \mathrm{a}, \mathrm{x}$ & $1.17 \pm 0.16 c, x$ & $28.08 \pm 1.06 \mathrm{~b}, \mathrm{x}$ & $9.03 \pm 1.15 \mathrm{~b}, \mathrm{x}$ \\
\hline & $\mathrm{NeCO}_{2}$ & $410 \pm 11 c, x$ & $400 \pm 18 b, x$ & $25.3 \pm 1.0 c, x$ & $11.5 \pm 1.5 \mathrm{~b}, \mathrm{x}$ & $4.73 \pm 0.47 c, x$ & $1.09 \pm 0.15 c, x$ & $26.20 \pm 1.64 \mathrm{~b}, \mathrm{x}$ & $9.45 \pm 0.98 \mathrm{~b}, \mathrm{x}$ \\
\hline & $(\mathrm{D}+\mathrm{N}) \mathrm{eCO}_{2}$ & $454 \pm 12 \mathrm{a}, \mathrm{x}$ & $438 \pm 10 \mathrm{a}, \mathrm{x}$ & $29.5 \pm 1.4 \mathrm{~b}, \mathrm{x}$ & $14.9 \pm 0.8 \mathrm{~b}, \mathrm{x}$ & $7.03 \pm 0.49 \mathrm{~b}, \mathrm{x}$ & $1.84 \pm 0.19 \mathrm{a}, \mathrm{x}$ & $29.67 \pm 0.82 \mathrm{~b}, \mathrm{x}$ & $9.79 \pm 0.72 b, x$ \\
\hline \multicolumn{10}{|l|}{ ANOVA } \\
\hline $\mathrm{CO}_{2}$ & & * & * & $* * *$ & * & $* *$ & * & $* *$ & $*$ \\
\hline AMF & & ns & ns & ns & * & ns & ns & ns & ns \\
\hline $\mathrm{eCO}_{2} \times \mathrm{AMF}$ & & ns & ns & * & * & ns & ns & ns & * \\
\hline
\end{tabular}

Data (means $\pm \mathrm{SE}, n=3$ ) followed by different letters indicate significant differences between $\mathrm{CO}_{2}$ treatments for the same AMF inoculation $(\mathrm{a}, \mathrm{b}, \mathrm{c}, \mathrm{d})$ and between AMF inoculations for the same $\mathrm{CO}_{2}$ treatment $(\mathrm{x}, \mathrm{y})$ at $p<0.05$. ANOVA: ns not significant; ${ }^{*},{ }^{* *}$ and ${ }^{* * *}$ indicate significant differences at $p \leq 0.05, p \leq 0.01$ and $p \leq 0.001$, respectively.

Elevated $\mathrm{CO}_{2}$ generally significantly decreased $\mathrm{N}$ in both the shoots and roots of AMF and non-AMF plants (Table 1), and such decreases were more pronounced under $\mathrm{NeCO}_{2}$ in AMF plants, and $\mathrm{DeCO}_{2}$ in non-AMF plants (Table 1). Reduction of shoot $\mathrm{P}$ concentrations were observed under both $\mathrm{NeCO}_{2}$ and $(\mathrm{D}+\mathrm{N}) \mathrm{eCO}_{2}$ in non-AMF plants and under $\mathrm{NeCO}_{2}$ in AMF plants only. Both $\mathrm{DeCO}_{2}$ and $\mathrm{NeCO}_{2}$ decreased root $\mathrm{P}$ concentrations in both AMF and non-AMF plants. $\mathrm{K}$ concentrations in the shoot and root were generally significantly lower under $\mathrm{eCO}_{2}$ than under $\mathrm{ACO}_{2}$ in both AMF and non-AMF plants (Table 1). Meanwhile, F. mosseae inoculation significantly increased root $\mathrm{N}$ concentrations under both $\mathrm{ACO}_{2}$ and $\mathrm{DeCO}_{2}$, leaf $\mathrm{N}$ concentrations under $\mathrm{DeCO}_{2}$ and root $\mathrm{P}$ concentrations under $\mathrm{DeCO}_{2}$ and $(\mathrm{D}+\mathrm{N}) \mathrm{eCO}_{2}$, and shoot $\mathrm{K}$ concentration under $\mathrm{NeCO}_{2}$. A significant $\mathrm{CO}_{2} \times$ AMF interaction was observed in $\mathrm{N}$ concentrations in both shoots and roots, and the $\mathrm{K}$ concentration in roots, but not for P concentrations (Table 1).

\subsection{Effects of $A M F$ and $\mathrm{CO}_{2}$ on Plant Biomass Production}

Elevated $\mathrm{CO}_{2}$ increased shoot, root and total plant biomass, regardless of whether the 12-week-old wheat seedlings were inoculated with F. mosseae or not (Figure 3A-C). Compared to the non-AMF plants, AMF colonization increased shoot and total plant biomass production, under $\mathrm{ACO}_{2}, \mathrm{DeCO}_{2}$ and $(\mathrm{D}+\mathrm{N}) \mathrm{eCO}$, but not under $\mathrm{NeCO}_{2}$ or for root biomass production (Figure $3 \mathrm{~B}$ ). Meanwhile, a significant $\mathrm{CO}_{2} \times \mathrm{AMF}$ interaction was found for both the shoot and total plant biomass production (Figure $3 \mathrm{~A}, \mathrm{C}$ ), but not for root biomass production (Figure 3B). 



Figure 3. Effects of $\mathrm{CO}_{2}$ and mycorrhiza on (A) shoot, (B) root, and (C) total plant biomass production; (D) shoot C, (E) root C, and (F) total plant C accumulation; (G) shoot N, (H) root N, and (I) total plant $\mathrm{N}$ accumulation; $(\mathbf{J})$ shoot $\mathrm{P},(\mathbf{K})$ root $\mathrm{P},(\mathbf{L})$ total plant $\mathrm{P}$ accumulation; and $(\mathbf{M})$ shoot $\mathrm{K},(\mathbf{N}) \operatorname{root} \mathrm{K},(\mathbf{O})$ total plant $\mathrm{K}$ accumulation in 12-week-old wheat grown under different daytime and/or nighttime $\mathrm{CO}_{2}$ concentrations inside environmentally controlled glass growth chambers. Values are the means \pm standard error (SE), $n=3$. Different letters above the bars indicate significant differences $(p<0.05)$, as revealed by Tukey's test. Statistical comparisons (two-way ANOVA) between $\mathrm{eCO}_{2}$ or AMF treatments, as well as their $\mathrm{eCO}_{2} \times \mathrm{AMF}$ interaction are presented for each variable. Abbreviations: $\mathrm{ACO}_{2}$, ambient $\mathrm{CO}_{2}$ (410 ppm daytime $+460 \mathrm{ppm}$ nighttime); $\mathrm{DeCO}_{2}$, elevated $\mathrm{CO}_{2}$ at daytime (550 ppm daytime +460 ppm nighttime); $\mathrm{NeCO}_{2}$, elevated $\mathrm{CO}_{2}$ at nighttime (410 ppm daytime + 610 ppm nighttime); $(\mathrm{D}+\mathrm{N}) \mathrm{eCO}$, elevated $\mathrm{CO}_{2}$ at both daytime and nighttime (550 ppm daytime + 610 ppm nighttime). Daytime: 07:00 a.m.-19:00 p.m. and nighttime: 19:00 p.m.-07:00 a.m. 


\subsection{Effects of $A M F$ and $\mathrm{CO}_{2}$ on Plant $C, N$ and $P$ Accumulations}

In general, $\mathrm{eCO}_{2}$ significantly increased $\mathrm{C}$ accumulations in the shoot, root and total plant of the 12-week-old wheat seedlings (Figure 3D-F). The $\mathrm{C}$ accumulations in the shoot and total plant were significantly affected by $F$. mosseae colonization and $\mathrm{CO}_{2} \times \mathrm{AMF}$ interaction (Figure 3D,F), but not in root $\mathrm{C}$ accumulations (Figure $3 \mathrm{E}$ ). The accumulations of $\mathrm{C}$ in the shoot and total plant were significantly higher for the AMF plants under $\mathrm{ACO}_{2}$, $\mathrm{DeCO}_{2}$ and $(\mathrm{D}+\mathrm{N}) \mathrm{eCO}_{2}$, but lower for the AMF plants under $\mathrm{NeCO}_{2}$, compared to the respective non-AMF plants (Figure 3D-F).

Generally, $\mathrm{eCO}_{2}$ significantly increased $\mathrm{N}$ accumulation in the shoot and total plant (Figure 3G,I), but not in the root (Figure 3H). Compared with non-AMF wheat plants, AMF plants had greater $\mathrm{N}$ accumulation in the shoot, root, and total plant under $\mathrm{ACO}_{2}, \mathrm{DeCO}_{2}$, and $(\mathrm{D}+\mathrm{N}) \mathrm{eCO}_{2}$ (Figure 3G-I), but lower under $\mathrm{NeCO}_{2}$ (Figure 3G,H). A significant $\mathrm{CO}_{2}$ $\times$ AMF interaction on $\mathrm{N}$ accumulation was thus observed in the shoot, root, and total plant (Figure 3G-I).

Compared with $\mathrm{ACO}_{2}, \mathrm{eCO}_{2}$ significantly enhanced $\mathrm{P}$ accumulation in the shoot by $35-95 \%$, and in the total plant by $30-79 \%$ in both non-AMF and AMF plants (Figure 3J,L), but had no effects on root $\mathrm{P}$ accumulation (Figure 3K). Neither the AMF symbiosis nor the $\mathrm{CO}_{2} \times$ AMF interaction showed a significant effect on the $\mathrm{P}$ accumulation in the shoot, root, and total plant (Figure 3J-L).

$\mathrm{K}$ accumulations in the shoot and total plant were significantly higher under all $\mathrm{eCO}_{2}$ treatments in non-AMF plants, and under $\mathrm{DeCO}_{2}$ and $(\mathrm{D}+\mathrm{N}) \mathrm{eCO}_{2}$ in AMF plants, compared with $\mathrm{ACO}_{2}(p<0.05$, Figure $3 \mathrm{M}, \mathrm{O})$. Significantly higher $\mathrm{K}$ accumulations in the shoot and total plant were in AMF than in non-AMF plants under $\mathrm{ACO}_{2}, \mathrm{DeCO}_{2}$, and (D+ $\mathrm{N}) \mathrm{CO}_{2}$. A significant $\mathrm{CO}_{2} \times \mathrm{AMF}$ interaction on $\mathrm{K}$ accumulation was thus observed in the shoot and total plant (Figure 3M,O), but not in root K accumulations (Figure 3N).

\subsection{Effects of $A M F$ and $\mathrm{CO}_{2}$ on Soil Nutrients}

Soil AN, AP, and AK were significantly affected by $\mathrm{CO}_{2}$, AMF, and $\mathrm{CO}_{2} \times \mathrm{AMF}$ interaction, regardless of whether plants were colonized with AMF or not (Figure $4 \mathrm{~A}-\mathrm{C}$ ). Compared with $\mathrm{ACO}_{2}$, soil $\mathrm{AN}, \mathrm{AP}$, and $\mathrm{AK}$ were significantly decreased under all $\mathrm{eCO}_{2}$ treatments in non-AMF soils, except $\mathrm{AP}$ under $\mathrm{NeCO}_{2}$, and under $\mathrm{DeCO}_{2}$ in $\mathrm{AMF}$ soils. Moreover, soil AN, AP, and AK were significantly increased by $5-36 \%, 7-49 \%$, and 3-31\% in $\mathrm{AMF}$ than in non-AMF soil under $\mathrm{eCO}_{2}$ (Figure $4 \mathrm{~A}-\mathrm{C}$ ).

\subsection{Effects of AMF and $\mathrm{CO}_{2}$ on Soil Enzymes Activity}

In general, $\mathrm{eCO}_{2}$ significantly increased the activity of soil invertase and urease (Figure $4 \mathrm{D}, \mathrm{E}$ ), but not the soil neutral phosphatase activity (Figure $4 \mathrm{~F}$ ) in both non-AMF and AMF plants. AMF colonization significantly increased the activity of invertase, urease, and neutral phosphatase (Figure 4D-F). Meanwhile, the $\mathrm{CO}_{2} \times \mathrm{AMF}$ interaction only resulted in significant positive changes in the invertase activity (Figure 4D), but not in both the urease (Figure 4E) and neutral phosphatase activity (Figure 4F). In addition, the activity of invertase, urease, and neutral phosphatase was significantly increased by $15-56 \%$, 19 $50 \%$, and $15-39 \%$ in AMF than in non-AMF soil under $\mathrm{ACO}_{2}, \mathrm{DeCO}_{2}$, and $(\mathrm{D}+\mathrm{N}) \mathrm{eCO}_{2}$, but not under $\mathrm{NeCO}_{2}$ (Figure $4 \mathrm{D}-\mathrm{F}$ ).

\subsection{Correlations}

Total plant biomass production was significantly negatively correlated to soil AN $(y=-0.10 x+12.08$, Figure $5 A)$ and soil AK $(y=-0.06 x+17.42$, Figure $5 C)$ in non-AMF plants, but not to AMF plants (Figure 5A,C). In contrast, no relationships between total plant biomass production and soil AP were observed in both AMF and non-AMF plants (Figure 5B). 

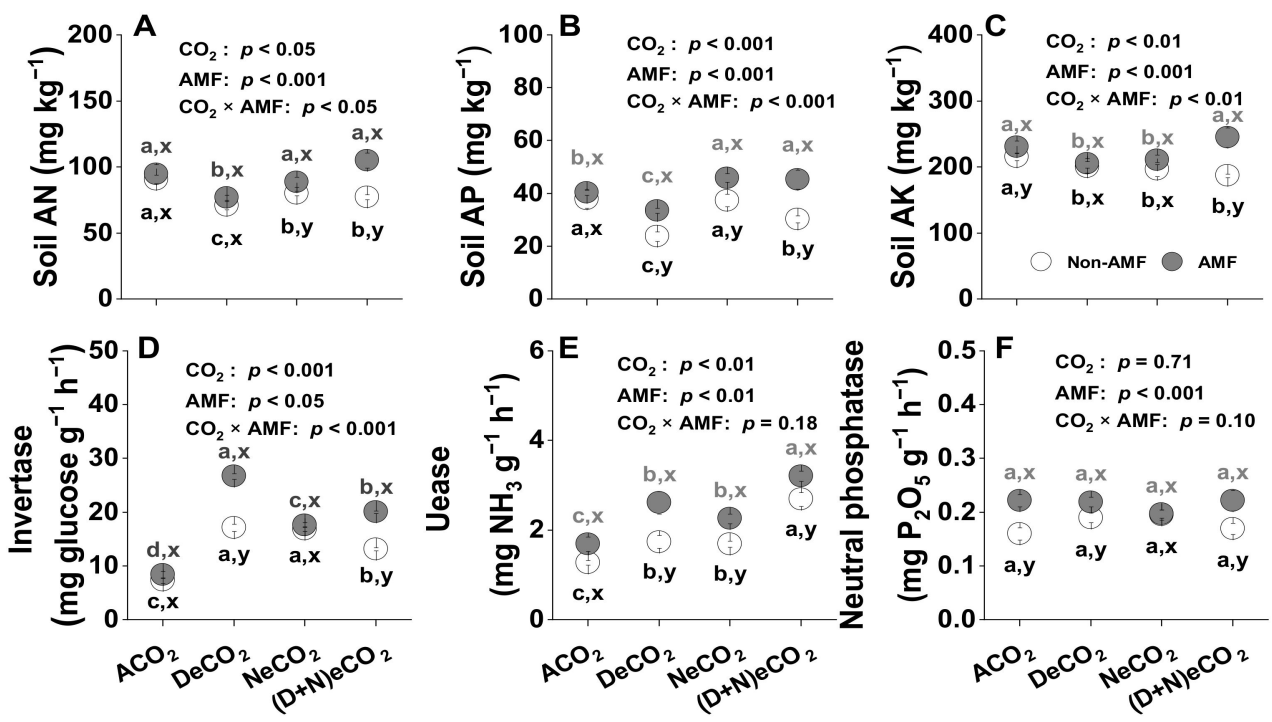

Figure 4. Effects of mycorrhiza and $\mathrm{CO}_{2}$ on (A) soil available nitrogen (AN), (B) soil available phosphorus (AP), (C) soil available potassium (AK), (D) invertase activity, (E) urease activity, and (F) neutral phosphatase activity in the soil of 12-week-old wheat grown under different daytime and/or nighttime $\mathrm{CO}_{2}$ concentrations inside environmentally controlled glass growth chambers. Values are the means $\pm \mathrm{SE}, n=3$. Different letters above the bars indicate significant differences $(p<0.05)$, as revealed by Tukey's test. Statistical comparisons (two-way ANOVA) between AMF and $\mathrm{CO}_{2}$ treatments, as well as their interaction $\left(\mathrm{eCO}_{2} \times \mathrm{AMF}\right)$ are presented for each variable. Abbreviations are the same as in Figure 2.



Figure 5. Relationships between plant biomass production and (A) soil available nitrogen (AN), (B) soil available phosphorus (AP), (C) soil available potassium (AK), (D) soil invertase, (E) urease or (F) neutral phosphatase in the soil of 12-week-old wheat grown under different daytime and/or nighttime $\mathrm{CO}_{2}$ concentrations inside environmentally controlled glass growth chambers. Data are means $\pm \mathrm{SE}, n=12$. Regressions are shown for non-AMF (dotted lines) and for AMF (solid lines) treatments. Abbreviations are the same as in Figure 2.

In addition, total plant biomass production was significantly positively correlated to the invertase activity in both AMF $(y=0.12 x+3.49)$ and non-AMF plants $(y=0.31 x+0.75$, Figure 5D), to the urease activity in AMF plants $(\mathrm{y}=1.30 \mathrm{x}+2.44)$, but not to non-AMF 
plants (Figure 5E), and to the phosphatase activity in non-AMF plants $(y=16.81 x+2.01)$, but not to AMF plants (Figure 5F).

\section{Discussion}

4.1. Effects of AMF Symbiosis on Plant Biomass and C Accumulation Depend on eCO $\mathrm{CO}_{2}$ at Daytime or Nighttime

Studies on the understanding of mycorrhizal- $\mathrm{CO}_{2}$ responses are mostly focused on the differences between $\mathrm{ACO}_{2}$ and 550-1000 ppm eCO $\mathrm{CO}_{2}$ at daytime [17,19,55]; no information about mycorrhizal plants responses to $\mathrm{eCO}_{2}$ at nighttime has been reported. As a substrate for plant photosynthesis, $\mathrm{eCO}_{2}$ during daytime facilitates $\mathrm{CO}_{2}$ assimilation processes by increasing intercellular $\mathrm{CO}_{2}$ and leaf carboxylation efficiency of ribulose-1,5-bisphosphate carboxylase/oxygenase (RubisCO) while reducing photorespiration [6,56,57], leading to an accumulation of non-structural carbohydrates and a stimulation of biomass production (Figure 3A-F). Meanwhile, a part of the photosynthetically-fixed C is consumed by leaves, shoots, and roots through dark respiration [58]. As a product of plant respiration, an increased intercellular $\mathrm{CO}_{2}$ and reduced stomata conductance under nighttime $\mathrm{eCO}_{2}$ [59] would lead to a decrease of plant dark respiration [48]. As a result, more biomass production was found in wheat grown under $410 / 610 \mathrm{ppm} \mathrm{NeCO}_{2}$ than under $410 / 460 \mathrm{ppm}$ $\mathrm{ACO}_{2}$ (Figure 3A-F), in line with earlier findings about Alfalfa [60], Phaseolus vulgaris [46], soybean [47], and Xanthium strumarium [44,47]. The decreased respiration was a physiological mechanism behind the increase in biomass by $\mathrm{C}$ conservation under $\mathrm{NeCO}_{2}[41,48,61]$.

Intriguingly, the most significant findings were that the pattern of plant response to $\mathrm{eCO}_{2}$ during daytime or nighttime was influenced by AMF inoculation. Plant growth depressions occur when increased nutrient benefits are outweighed by its $C$ cost, whereas positive growth responses occur where benefits outweigh the cost [62]. The positive growth responses to AMF inoculation were observed under $550 / 460 \mathrm{ppm} \mathrm{DeCO}_{2}$ and $550 / 610 \mathrm{ppm}$ $(\mathrm{D}+\mathrm{N}) \mathrm{eCO}_{2}$, whereas a negative effect under $410 / 610 \mathrm{ppm} \mathrm{NeCO}_{2}$ on wheat growth and $\mathrm{C}$ accumulation was found in the present study (Figure 3A-F). With low daytime $\mathrm{CO}_{2}$ and high nighttime $\mathrm{CO}_{2}$, photosynthetic responses did not predominately control plant growth [43]. AMF colonization would drain more photo-assimilates from the host plant for extraradical hyphal growth [25] and increase mycorrhizal respiration under $\mathrm{eCO}_{2}$ than under $\mathrm{ACO}_{2}[37,63]$, leading to reduced pools of nonstructural carbohydrates in the host and growth depression under $\mathrm{NeCO}_{2}$ (Figure 3A-F). With high $\mathrm{CO}_{2}$ concentration at daytime, plant $C$ utilization by AMF might be compensated by higher photosynthesis in host plants [64]. AMF would enhance more photo-assimilate production than that they could drain from the host plant due to an improved nutrient uptake, leading to a positive effect under $\mathrm{DeCO}_{2}$ and $(\mathrm{D}+\mathrm{N}) \mathrm{eCO}_{2}$ (Figure $\left.3 \mathrm{~A}-\mathrm{F}\right)$, which is in line with that reported by Zhu et al. [65], who concluded that AMF (Rhizophagus irregularis)-colonized wheat achieved greater growth and higher $\mathrm{C}$ accumulation than non-AMF wheat at $700 \mathrm{ppm}(\mathrm{D}+$ $\mathrm{N}) \mathrm{eCO}_{2}$ [65]. Thus, resource limitation is a key factor in the cost-benefit analysis of AMF effects on plant growth under $\mathrm{NeCO}_{2}$.

\subsection{Nitrogen Demands are Increased under e $\mathrm{CO}_{2}$, but AMF Symbiosis Lessens $\mathrm{N}$ Limitation under e $\mathrm{CO}_{2}$ at Daytime, Not at Nighttime}

Our results showed that $\mathrm{eCO}_{2}$ at daytime and/or nighttime caused a decrease in $\mathrm{N}$ concentrations of the shoot and root both in non-AMF and AMF wheat (Table 1), which was similar to earlier reports that tissue $\mathrm{N}$ concentrations were often decreased in wheat cultivars under 550-800 ppm eCO 2 [25,32,65-67]. The following mechanisms could explain the decreased $\mathrm{N}$ in plants under $\mathrm{eCO}_{2}$ both at daytime and nighttime: (1) a "dilution effect" due to higher plant biomass production $[9,68]$; (2) reduced transpiration rates under $\mathrm{eCO}_{2}$ both at daytime and nighttime could decrease the transpiration-driven mass flow of nutrients, and hence, induced limitations in leaf nutrient transport led to decreased $\mathrm{N}$ uptake $[66,69,70]$; and (3) the reduction of the RubisCO protein that constitutes about half of the protein in leaves under $\mathrm{eCO}_{2}$ both at daytime and nighttime [48,71]. Beyond that, we speculated that the inhibition of leaf $\mathrm{N}$ assimilation under $\mathrm{eCO}_{2}$ was associated 
with the reduction in respiration. The reduced respiration under high $\mathrm{CO}_{2}$ has led to a reduced supply of energy-rich compounds, including ATP and NADH in the cytoplasm, and thereby decreases the amount of reductant available for $\mathrm{NO}_{3}{ }^{-}$reduction [72,73].

The $\mathrm{N}$ concentrations of shoots and roots and the $\mathrm{P}$ concentration of roots were higher in AMF plants than in non-AMF counterparts grown under $\mathrm{DeCO}_{2}$, whereas they were not affected by AM fungal colonization under $\mathrm{NeCO}_{2}$ (Table 1). $\mathrm{NeCO}_{2}$ hence resulted in a decrease in beneficial effects of AMF on plants. An enhanced $\mathrm{C}$ fixation under $\mathrm{DeCO}_{2}$ would require more supply of $\mathrm{N}, \mathrm{P}$ and $\mathrm{K}$, leading to a strong decline in soil $\mathrm{AN}, \mathrm{AP}$, and $\mathrm{AK}$ associated with $\mathrm{DeCO}_{2}$ (Figure $4 \mathrm{~A}-\mathrm{C}$ ). Thus, F. mosseae colonization promoted plant uptake of $\mathrm{N}, \mathrm{P}$, and $\mathrm{K}$, and alleviated plant nutrient demands and soil N, P, and $\mathrm{K}$ limitations under $\mathrm{eCO}_{2}$ at the daytime. In contrast, $\mathrm{eCO}_{2}$ at nighttime decreased the dark respiration, resulting in reduced energy and nutrient demands [44]. In general, plants in nutrient-rich soils under $\mathrm{NeCO}_{2}$ (Figure $4 \mathrm{~B}, \mathrm{C}$ ) tend to be less frequently affected by AM fungi [74].

Although plant $\mathrm{N}$ concentrations were decreased due to $\mathrm{CO}_{2}$ elevation, $\mathrm{N}$ accumulation in wheat tissues was enhanced because of an increased biomass in both non-AMF and AMF plants (Figure 3G-I). Similar to our findings, compared to non-AMF plants, leaf N\% or plant total $\mathrm{N}$ accumulation under $700-1000 \mathrm{ppm} \mathrm{eCO} 2$ was increased by $30-41 \%$ in AMF colonized wheat [65], alfalfa [36], and Taraxacum officinale [31]. The significantly higher $\mathrm{N}$ in AMF plants might be due to a higher $\mathrm{C}$ accumulation from photosynthesis and hence a greater $\mathrm{N}$ demand under daytime $\mathrm{eCO}_{2}$. In contrast, we found a negative $\mathrm{AM}$ effect on plant $\mathrm{N}$ uptake under nighttime $\mathrm{eCO}_{2}$ (Figure $3 \mathrm{G}-\mathrm{I}$ ). One possible explanation could be that $\mathrm{eCO}_{2}$ inhibited the assimilation of $\mathrm{NO}_{3}{ }^{-}$[72], which is the dominant inorganic $\mathrm{N}$ form in dryland soils. The $\mathrm{NO}_{3}{ }^{-}$assimilation of Arabidopsis and wheat was slowed down under $720 \mathrm{ppm}$ nighttime $\mathrm{eCO}_{2}$ [72]. Thus, both the $\mathrm{N}$ form and atmospheric $\mathrm{CO}_{2}$ concentration at nighttime are important factors in determining plant performance.

\section{3. $\mathrm{P}$ and $\mathrm{K}$ Demands were Increased under $\mathrm{CCO}_{2}$ at Daytime, Not at Nighttime}

Shoot and root $\mathrm{P}$ or $\mathrm{K}$ concentrations were decreased under $\mathrm{eCO}_{2}$, regardless of AMF status (Table 1). These results agreed with how tissue $\mathrm{P}$ and $\mathrm{K}$ concentrations in various legumes and non-legumes were often lower under 550-800 ppm eCO $\mathrm{CO}_{2}$ than under $\mathrm{ACO}_{2}$ because of an increase in dry matter and carbohydrate accumulation $[4,25,75,76]$. Such lower P or K concentrations in plant tissues could be alleviated by AMF colonization in some, but not in all cases. For example, leaf and root $\mathrm{P}$ concentrations in non-mycorrhizal T. repens declined by $31 \%$ and $115 \%$ under $700 \mathrm{ppm} \mathrm{eCO}$, whereas in $F$. mosseae seedlings, the decline in P concentration was as low as $17 \%$ and $0.5 \%$, respectively [77]. R. intraradices stimulated the growth and $\mathrm{P}$ acquisition of sour orange, but not of sweet orange grown at high P (2 mM) supply under $700 \mathrm{ppm} \mathrm{eCO} 2$ [37]. The growth of Medicago truncatula and Brachypodium distachyon under $900 \mathrm{ppm} \mathrm{eCO}$ was increased by sufficient $\mathrm{P}$ supply, rather than by $R$. irregularis colonization [9]. $\mathrm{eCO}_{2}$ at $700 \mathrm{ppm}$ resulted in a $20 \%$ or $22 \%$ decrease of $\mathrm{K}$ in grains of non-mycorrhizal or mycorrhizal durum wheat [33]. In general, plants have developed specific $\mathrm{P}$ acquisition strategies by root systems and/or mycorrhizal associations to take up limited $\mathrm{P}$ in the soil [78-80]. Plant $\mathrm{P}$ and $\mathrm{K}$ acquisition is obviously enhanced by extensive root development. The $\mathrm{P}$ and $\mathrm{K}$ concentration influences plant photosynthesis and growth rates, leading to multiple $\mathrm{C}-\mathrm{P}$ and $\mathrm{C}-\mathrm{K}$ interactions $550 \mathrm{ppm}$ $\mathrm{DeCO}_{2}$ (Figure 3J-O) while $610 \mathrm{ppm} \mathrm{NeCO}$ did not increase shoot, root, or total plant $\mathrm{P}$ and $\mathrm{K}$ content (Figure 3J-O). The different response to $\mathrm{DeCO}_{2}$ and $\mathrm{NeCO}_{2}$ may be related to photosynthesis. As a general rule, AMF symbiosis delivered soil N, P, and $\mathrm{K}$ to plants in return for photosynthate, alleviating plant $\mathrm{N}, \mathrm{P}$, and $\mathrm{K}$ demands, resulting in increased growth responses to $\mathrm{eCO}_{2}$ via positive feedback [3]. Thus, $\mathrm{AMF}$ symbiosis might alter the imbalance of sink and source under $\mathrm{eCO}_{2}$ by regulating the demand for $\mathrm{C}$ and supply of $\mathrm{N}$, P, and K from the soil to the host plant [35]. However, our results showed that AMF colonization had no significant effects on $\mathrm{P}$ accumulations in the shoot and root and $\mathrm{K}$ accumulation in the root (Table 1, Figure 3J-L,N). The mechanisms affecting P, K absorption 
and metabolism in crops under AMF symbiosis and varied daytime and nighttime $\mathrm{eCO}_{2}$ needs further research in the future.

\subsection{AMF Colonization Increased Soil N, P and K availability, Especially under eCO $\mathrm{CO}_{2}$ at Daytime}

Plant-soil interactive feedback to $\mathrm{eCO}_{2}$ likely determines the increase or decrease in soil N, P, and $\mathrm{K}$ pools, as well as microbial community composition and activities. In general, $\mathrm{C}$ flows into the soil through the plant root and/or mycorrhiza directly or indirectly. Under $\mathrm{eCO}_{2}$, more $\mathrm{C}$ was available for mycorrhizal growth and development, and AMF associations were thus stimulated by such extra C [81]. In turn, AMF accelerates soil organic matter decomposition under $\mathrm{eCO}_{2}$ to mine for $\mathrm{N}$ and $\mathrm{P}$ [19]. The increase of invertase and urease activity under 500-610 ppm eCO 2 indicated higher decomposition of organic $\mathrm{C}-\mathrm{N}$-compounds and release of $\mathrm{N}$ and other nutrients, resulting in a general activation of microbes [82]. The relative increases in soil enzyme activities also might be attributed to a higher biomass production under $\mathrm{eCO}_{2}\left(\mathrm{R}^{2}=0.46-0.77, p<0.001\right.$, Figure $\left.5 \mathrm{~A}, \mathrm{D}-\mathrm{F}\right)$, and hence a greater demand of $\mathrm{N}, \mathrm{P}$, and $\mathrm{K}$ [3]. In fact, the considerable decrease in available $\mathrm{N}$, $\mathrm{P}$, and $\mathrm{K}$ under $\mathrm{DeCO}_{2}$ in the present study supports this view. A meta-analysis showed that $\mathrm{eCO}_{2}$-induced nutrient limitation could increase soil enzyme activities [83]. However, a significantly higher level of soil AN, AP and AK was observed in AMF wheat seedlings than in non-AMF counterparts under $\mathrm{eCO}_{2}$ (Figure $4 \mathrm{~A}-\mathrm{C}$ ), suggesting that the presence of AM fungi could confer better soil fertility under $\mathrm{eCO}_{2}$.

\section{Conclusions}

The present study under auto-simulated future daytime and/or nighttime $\mathrm{eCO}_{2}$ provides evidence that $\mathrm{eCO}_{2}$ can impact plant-soil feedback and/or plant-AMF symbiosis. Our results showed that the responses of crops to an averaged sole daytime/nighttime $\mathrm{eCO}_{2}$ might not provide the expected effects of rising $\mathrm{CO}_{2}$ concentration that they could have on crop growth. More soil N, P, and $\mathrm{K}$ nutrients were required under $\mathrm{DeCO}_{2}$ to match increased $\mathrm{C}$ assimilation, leading to lower soil N, P, and $\mathrm{K}$ availability. Although F. mosseae colonization alleviated soil nutrient constraints in response to $\mathrm{eCO}_{2}$, its role on plant growth depended on $\mathrm{eCO}_{2}$ at daytime and/or nighttime, which could induce an imbalance in the source-sink relationship associated with reduced plant and soil N, P, and K. AMF symbiosis could improve plant $\mathrm{C}$ accumulation, $\mathrm{N}, \mathrm{P}$, and $\mathrm{K}$ uptake particularly under $\mathrm{DeCO}_{2}$, while $\mathrm{NeCO}_{2}$ decreased AMF's beneficial effects on plants. Such information is essential for understanding the mechanisms influencing $\mathrm{C}, \mathrm{N}, \mathrm{P}$, and $\mathrm{K}$ dynamics in future climate-change scenarios. As a result, integrating $\mathrm{AMF}^{\prime} \mathrm{s}$ benefits to plants under a factual field $\mathrm{DeCO}_{2}$ and $\mathrm{NeCO}_{2}$ will be critical when dealing with the long-term consequence of future $\mathrm{CO}_{2}$ rising on global cropping systems.

Supplementary Materials: The following are available online at https:/ /www.mdpi.com/article/10 .3390 /jof7060458/s1, Figure S1: Average daily (A, $417 \pm 16 / 463 \pm 27$ ppm, means \pm SD, $n=175$, daytime (7:00 a.m.-19:00 p.m.)/nighttime (19:00 p.m.-7:00 a.m.)) and weekly (B, $421 \pm 19 / 467 \pm$ $18 \mathrm{ppm}$, means $\pm \mathrm{SD}, n=25$, daytime/nighttime) variations of atmospheric CO2 concentrations between October 2017 and March 2018 in the National Monitoring Base for Purple Soil Fertility and Fertilizer Efficiency $\left(29^{\circ} 48^{\prime} \mathrm{N}, 106^{\circ} 24^{\prime} \mathrm{E}, 266.3 \mathrm{~m}\right.$ above the sea level) on the campus of Southwest University, Chongqing, China.The atmosphere $\mathrm{CO} 2$ concentrations were monitored by an autocontrolled facility (DSS-QZD, Qingdao Shengsen Institute of Science and Technology, Shandong, China). Figure $\mathrm{S} 2$ : $\mathrm{CO}_{2}$ auto-controlling facility (A) overview of environmentally controlled growth chambers, (B-C) $\mathrm{CO}_{2}$ digital control screen, (D) the humidity, temperature, light and $\mathrm{CO}_{2}$ sensors, (E-F) $\mathrm{CO}_{2}$ gas cylinder, $(\mathrm{G})$ the control system.

Author Contributions: S.S. (Songmei Shi) and X.H. conceived and designed the experiments; X.L., M.W. and X.D. performed the pots experiments and collected the samples. S.S. (Songmei Shi) and X.L. analyzed the data and wrote the paper. S.S. (Sharifullah Sharifi), D.X. and X.H. polished the English to improve the quality of this manuscript. All authors have read and agreed to the published version of the manuscript. 
Funding: This study was jointly supported by National Youth Natural Science Foundation of China (4111800096), Science and Technology Department of Sichuan Province (2018JZ0027), Biological Science Research Center at Southwest University (100030/2120054019) and Key Laboratory of Ecoenvironments in Three Gorges Reservoir Region (Ministry of Education), Chongqing, China.

Institutional Review Board Statement: Not applicable.

Informed Consent Statement: Not applicable.

Data Availability Statement: Not applicable.

Conflicts of Interest: The authors declare no conflict of interest.

\section{References}

1. IPCC. Climate Change 2014: Synthesis Report. In Contribution of Working Groups I, II and III to the Fifth Assessment Report of the Intergovernmental Panel on Climate Change; Pachauri, R.K., Meyer, L.A., Eds.; IPCC: Geneva, Switzerland, $2014 ;$ p. 151.

2. Kuzyakov, Y.; Horwath, W.R.; Dorodnikov, M.; Blagodatskaya, E. Review and synthesis of the effects of elevated atmospheric $\mathrm{CO}_{2}$ on soil processes: No changes in pools, but increased fluxes and accelerated cycles. Soil Biol. Biochem. 2019, 128, 66-78. [CrossRef]

3. Singh, A.K.; Rai, A.; Kushwaha, M.; Chauhan, P.S.; Pandey, V.; Singh, N. Tree growth rate regulate the influence of elevated $\mathrm{CO}_{2}$ on soil biochemical responses under tropical condition. J. Environ. Manag. 2019, 231, 1211-1221. [CrossRef]

4. Shi, S.; Luo, X.; Dong, X.; Qiu, Y.; Xu, C.; He, X. Arbuscular mycorrhization enhances nitrogen, phosphorus and potassium accumulation in Vicia faba by modulating soil nutrient balance under elevated $\mathrm{CO}_{2}$. J. Fungi 2021, 7, 361. [CrossRef]

5. Halpern, M.; Bar-Tal, A.; Lugassi, N.; Egbaria, A.; Granot, D.; Yermiyahu, U. The role of nitrogen in photosynthetic acclimation to elevated $\left[\mathrm{CO}_{2}\right]$ in tomatoes. Plant Soil 2019, 434, 397-411. [CrossRef]

6. Dusenge, M.E.; Duarte, A.G.; Way, D.A. Plant carbon metabolism and climate change: Elevated $\mathrm{CO}_{2}$ and temperature impacts on photosynthesis, photorespiration and respiration. New Phytol. 2019, 221, 32-49. [CrossRef] [PubMed]

7. Singer, S.D.; Soolanayakanahally, R.Y.; Foroud, N.A.; Kroebel, R. Biotechnological strategies for improved photosynthesis in a future of elevated atmospheric $\mathrm{CO}_{2}$. Planta 2020, 251, 24. [CrossRef]

8. Aljazairi, S.; Arias, C.; Nogués, S.; Loreto, F. Carbon and nitrogen allocation and partitioning in traditional and modern wheat genotypes under pre-industrial and future $\mathrm{CO}_{2}$ conditions. Plant Biol. 2015, 17, 647-659. [CrossRef] [PubMed]

9. Jakobsen, I.; Smith, S.E.; Smith, F.A.; Watts-Williams, S.J.; Clausen, S.S.; Gronlund, M. Plant growth responses to elevated atmospheric $\mathrm{CO}_{2}$ are increased by phosphorus sufficiency but not by arbuscular mycorrhizas. J. Exp. Bot. 2016, 67, 6173-6186. [CrossRef]

10. Terrer, C.; Jackson, R.B.; Prentice, I.C.; Keenan, T.F.; Kaiser, C.; Vicca, S.; Fisher, J.B.; Reich, P.B.; Stocker, B.D.; Hungate, B.A. Nitrogen and phosphorus constrain the $\mathrm{CO}_{2}$ fertilization of global plant biomass. Nat. Clim. Chang. 2019, 9, 684-689. [CrossRef]

11. Bloom, A.J.; Burger, M.; Kimball, B.A.; Pinter, P.J., Jr. Nitrate assimilation is inhibited by elevated $\mathrm{CO}_{2}$ in field-grown wheat. Nat. Clim. Chang. 2014, 4, 477-480. [CrossRef]

12. Tausz, M.; Norton, R.M.; Tausz-Posch, S.; Löw, M.; Seneweera, S.; O’Leary, G.; Armstrong, R.; Fitzgerald, G.J. Can additional $\mathrm{N}$ fertiliser ameliorate the elevated $\mathrm{CO}_{2}$-induced depression in grain and tissue $\mathrm{N}$ concentrations of wheat on a high soil $\mathrm{N}$ background? J. Agron. Crop Sci. 2017, 203, 574-583. [CrossRef]

13. Reich, P.B.; Hobbie, S.E.; Lee, T.; Ellsworth, D.S.; West, J.B.; Tilman, D.; Knops, J.M.H.; Naeem, S.; Trost, J. Nitrogen limitation constrains sustainability of ecosystem response to $\mathrm{CO}_{2}$. Nature 2006, 440, 922-925. [CrossRef]

14. Wang, S.; Zhang, Y.; Ju, W.; Chen, J.M.; Ciais, P.; Cescatti, A.; Peñuelas, J. Recent global decline of $\mathrm{CO}_{2}$ fertilization effects on vegetation photosynthesis. Science 2020, 370, 1295-1300. [CrossRef]

15. Du, C.; Wang, X.; Zhang, M.; Jing, J.; Gao, Y. Effects of elevated $\mathrm{CO}_{2}$ on plant C-N-P stoichiometry in terrestrial ecosystems: A meta-analysis. Sci. Total Environ. 2019, 650, 697-708. [CrossRef] [PubMed]

16. Li, Y.; Yu, Z.; Yang, S.; Wang, G.; Liu, X.; Wang, C.; Xie, Z.; Jin, J. Impact of elevated $\mathrm{CO}_{2}$ on C:N:P ratio among soybean cultivars. Sci. Total Environ. 2019, 694, 133784. [CrossRef]

17. Treseder, K.K. A meta-analysis of mycorrhizal responses to nitrogen, phosphorus, and atmospheric $\mathrm{CO}_{2}$ in field studies. New Phytol. 2004, 164, 347-355. [CrossRef]

18. Zhu, C.W.; Kobayashi, K.; Loladze, I.; Zhu, J.G.; Jiang, Q.; Xu, X.; Liu, G.; Seneweera, S.; Ebi, K.L.; Drewnowski, A.; et al. Carbon dioxide $\left(\mathrm{CO}_{2}\right)$ levels this century will alter the protein, micronutrients, and vitamin content of rice grains with potential health consequences for the poorest rice-dependent countries. Sci. Adv. 2018, 4, 1-8. [CrossRef] [PubMed]

19. Cheng, L.; Booker, F.L.; Tu, C.; Burkey, K.O.; Zhou, L.; Shew, H.D.; Rufty, T.W.; Hu, S. Arbuscular mycorrhizal fungi increase organic carbon decomposition under elevated $\mathrm{CO}_{2}$. Science 2012, 337, 1084-1087. [CrossRef]

20. Usyskin-Tonne, A.; Hadar, Y.; Yermiyahu, U.; Minz, D. Elevated $\mathrm{CO}_{2}$ has a significant impact on denitrifying bacterial community in wheat roots. Soil Biol. Biochem. 2020, 142, 1-10. [CrossRef]

21. Panneerselvam, P.; Kumar, U.; Senapati, A.; Parameswaran, C.; Anandan, A.; Kumar, A.; Jahan, A.; Padhy, S.R.; Nayak, A.K. Influence of elevated $\mathrm{CO}_{2}$ on arbuscular mycorrhizal fungal community elucidated using Illumina MiSeq platform in sub-humid tropical paddy soil. Appl. Soil Ecol. 2020, 145, 103344. [CrossRef] 
22. Aon, M.A.; Cabello, M.N.; Sarena, D.E.; Colaneri, A.C.; Franco, M.G.; Burgos, J.L.; Cortassa, S. Spatio-temporal patterns of soil microbial and enzymatic activities in an agricultural soil. Appl. Soil Ecol. 2001, 18, 239-254. [CrossRef]

23. Gill, R.A.; Anderson, L.J.; Polley, H.W.; Johnson, H.B.; Jackson, R.B. Potential nitrogen constraints on soil carbon sequestration under low and elevated atmospheric $\mathrm{CO}_{2}$. Ecology 2006, 87, 41-52. [CrossRef] [PubMed]

24. Smith, S.E.; Read, D.J. The symbionts forming arbuscular mycorrhizas. In Mycorrhizal Symbiosis, 3rd ed.; Academic Press: London, UK, 2008; pp. 13-41.

25. Thirkell, T.J.; Pastok, D.; Field, K.J. Carbon for nutrient exchange between arbuscular mycorrhizal fungi and wheat varies according to cultivar and changes in atmospheric carbon dioxide concentration. Glob. Chang. Biol. 2019, 26, 1725-1738. [CrossRef]

26. Saleh, A.M.; Abdelmawgoud, M.; Hassan, A.R.; Habeeb, T.H.; Yehia, R.S.; Abdelgawad, H. Global metabolic changes induced by arbuscular mycorrhizal fungi in oregano plants grown under ambient and elevated levels of atmospheric $\mathrm{CO}_{2}$. Plant Physiolo. Biochem. 2020, 151, 255-263. [CrossRef] [PubMed]

27. Dong, Y.; Wang, Z.; Sun, H.; Yang, W.; Xu, H. The response patterns of arbuscular mycorrhizal and ectomycorrhizal symbionts under elevated $\mathrm{CO}_{2}$ : A meta-analysis. Front. Microbiol. 2018, 9, 1248. [CrossRef]

28. Terrer, C.; Vicca, S.; Hungate, B.A.; Phillips, R.P.; Prentice, I.C. Mycorrhizal association as a primary control of the $\mathrm{CO}_{2}$ fertilization effect. Science 2016, 353, 72-74. [CrossRef] [PubMed]

29. Baslam, M.; Erice, G.; Goicoechea, N. Impact of arbuscular mycorrhizal fungi (AMF) and atmospheric $\mathrm{CO}_{2}$ concentration on the biomass production and partitioning in the forage legume alfalfa. Symbiosis 2012, 58, 171-181. [CrossRef]

30. Baslam, M.; Antolín, M.C.; Gogorcena, Y.; Muñoz, F.; Goicoechea, N. Changes in alfalfa forage quality and stem carbohydrates induced by arbuscular mycorrhizal fungi and elevated atmospheric $\mathrm{CO}_{2}$. Ann. Appl. Biol. 2014, 164, 190-199. [CrossRef]

31. Becklin, K.M.; Mullinix, G.W.; Ward, J.K. Host plant physiology and mycorrhizal functioning shift across a glacial through future $\left[\mathrm{CO}_{2}\right.$ ] gradient. Plant Physiol. 2016, 172, 789-801. [CrossRef]

32. Butterly, C.R.; Armstrong, R.; Chen, D.; Tang, C. Carbon and nitrogen partitioning of wheat and field pea grown with two nitrogen levels under elevated $\mathrm{CO}_{2}$. Plant Soil 2015, 391, 367-382. [CrossRef]

33. Goicoechea, N.; Bettoni, M.M.; Fuertes-Mendizabal, T.; González-Murua, C.; Aranjuelo, I. Durum wheat quality traits affected by mycorrhizal inoculation, water availability and atmospheric $\mathrm{CO}_{2}$ concentration. Crop Pasture Sci. 2016, 67, 147-155. [CrossRef]

34. Garmendia, I.; Gogorcena, Y.; Aranjuelo, I.; Goicoechea, N. Responsiveness of durum wheat to mycorrhizal inoculation under different environmental scenarios. J. Plant Growth Regul. 2017, 36, 855-867. [CrossRef]

35. Cavagnaro, T.; Gleadow, R.; Miller, R. Plant nutrient acquisition and utilisation in a high carbon dioxide world. Funct. Plant Biol. 2011, 38, 87-96. [CrossRef] [PubMed]

36. Goicoechea, N.; Baslam, M.; Erice, G.; Irigoyen, J.J. Increased photosynthetic acclimation in alfalfa associated with arbuscular mycorrhizal fungi (AMF) and cultivated in greenhouse under elevated $\mathrm{CO}_{2}$. J. Plant Physiol. 2014, 171, 1774-1781. [CrossRef] [PubMed]

37. Jifon, J.L.; Graham, J.H.; Drouillard, D.L.; Syvertsen, J.P. Growth depression of mycorrhizal citrus seedlings grown at high phosphorus supply is mitigated by elevated $\mathrm{CO}_{2}$. New Phytol. 2002, 153, 133-142. [CrossRef]

38. Ziska, L.H.; Ghannoum, O.; Baker, J.; Conroy, J.; Bunce, J.A.; Kobayashi, K.; Okada, M. A global perspective of ground level,'ambient'carbon dioxide for assessing the response of plants to atmospheric $\mathrm{CO}_{2}$. Glob. Chang. Biol. 2001, 7, 789-796.

39. Shi, S.; Qiu, Y.; Wen, M.; Xu, X.; Dong, X.; Xu, C.; He, X. Daytime, not nighttime, elevated atmospheric carbon dioxide exposure improves plant growth and leaf quality of mulberry (Morus alba L.) seedlings. Front Plant Sci 2021, 11, 609031. [CrossRef] [PubMed]

40. Bunce, J. Seed yield of soybeans with daytime or continuous elevation of carbon dioxide under field conditions. Photosynthetica 2005, 43, 435-438. [CrossRef]

41. Bunce, J. Carbon dioxide concentration at night affects translocation from soybean leaves. Ann. Bot. 2002, 90, 399-403. [CrossRef] [PubMed]

42. Bunce, J. Responses of seedling growth to daytime or continuous elevation of carbon dioxide. Int. J. Plant Sci. 2003, 164, 377-382. [CrossRef]

43. Bunce, J. The response of soybean seedling growth to carbon dioxide concentration at night in different thermal regimes. Biotronics 2001, 30, 15-26.

44. Reuveni, J.; Gale, J.; Zeroni, M. Differentiating day from night effects of high ambient $\left[\mathrm{CO}_{2}\right]$ on the gas exchange and growth of Xanthium strumarium L. exposed to salinity stress. Ann. Bot. 1997, 79, 191-196. [CrossRef]

45. Ziska, L.H.; Bunce, J.A. Effect of elevated carbon dioxide concentration at night on the growth and gas exchange of selected C4 species. Aust.J. Plant Physiol. 1999, 26, 71-77. [CrossRef]

46. Bunce, J. $\mathrm{CO}_{2}$ enrichment at night affects the growth and yield of common beans. Crop Sci. 2014, 54, 1744-1747. [CrossRef]

47. Bunce, J. Effects of elevated carbon dioxide concentration in the dark on the growth of soybean seedlings. Ann. Bot. 1995, 75, 365-368. [CrossRef]

48. Griffin, K.; Sims, D.; Seemann, J. Altered night-time $\mathrm{CO}_{2}$ concentration affects the growth, physiology and biochemistry of soybean. Plant Cell Environ. 1999, 22, 91-99. [CrossRef]

49. Amthor, J.S.; Koch, G.W.; Bloom, A.J. $\mathrm{CO}_{2}$ inhibits respiration in leaves of Rumex crispus L. Plant Physiol. 1992, 98, 757-760. [CrossRef] [PubMed] 
50. Poorter, H.; Gifford, R.M.; Kriedemann, P.E.; Wong, S.C. A quantitative-analysis of dark respiration and carbon content as factors in the growth-response of plants to elevated $\mathrm{CO}_{2}$. Aust. J. Bot. 1992, 40, 501-513. [CrossRef]

51. Brundrett, M.; Bougher, N.; Dell, B.; Grove, T.; Malajczuk, N. Working with Mycorrhizas in Forestry and Agriculture; RePEc: Canberra, Australian, 1996; pp. 173-212.

52. Yang, J.; Wang, C.; Dai, H. Soil Agrochemical Analysis and Environmental Monitoring Techniques; Chinese Dadi Press: Beijing, China, 2008; pp. 18-64.

53. Ren, C.; Kang, D.; Wu, J.P.; Zhao, F.; Yang, G.; Han, X.; Feng, Y.; Ren, G. Temporal variation in soil enzyme activities after afforestation in the Loess Plateau, China. Geoderma 2016, 282, 103-111. [CrossRef]

54. Wu, Q.S.; Li, Y.; Zou, Y.N.; He, X.H. Arbuscular mycorrhiza mediates glomalin-related soil protein production and soil enzyme activities in the rhizosphere of trifoliate orange grown under different P levels. Mycorrhiza 2015, 25, 121-130. [CrossRef] [PubMed]

55. Panneerselvam, P.; Sahoo, S.; Senapati, A.; Kumar, U.; Mitra, D.; Parameswaran, C.; Anandan, A.; Kumar, A.; Jahan, A.; Nayak, A.K. Understanding interaction effect of arbuscular mycorrhizal fungi in rice under elevated carbon dioxide conditions. J. Basic Microb. 2019, 59, 1217-1228. [CrossRef]

56. Thomey, M.L.; Slattery, R.A.; Kohler, I.H.; Bernacchi, C.J.; Ort, D.R. Yield response of field-grown soybean exposed to heat waves under current and elevated $\left[\mathrm{CO}_{2}\right.$ ]. Glob Chang Biol. 2019, 25, 4352-4368. [CrossRef]

57. Ahammed, G.J.; Li, X.; Liu, A.; Chen, S. Physiological and defense responses of tea plants to elevated $\mathrm{CO}_{2}$ : A review. Front. Plant Sci. 2020, 11, 305. [CrossRef] [PubMed]

58. Eisenhut, M.; Roell, M.S.; Weber, A.P.M. Mechanistic understanding of photorespiration paves the way to a new green revolution. New Phytol. 2019, 233, 1762-1769. [CrossRef] [PubMed]

59. Mao, Q.; Tang, L.; Ji, W.; Rennenberg, H.; Hu, B.; Ma, M. Elevated $\mathrm{CO}_{2}$ and soil mercury stress affect photosynthetic characteristics and mercury accumulation of rice. Ecotoxicol. Environ. Saf 2021, 208, 111605. [CrossRef]

60. Reuveni, J.; Gale, J. The effect of high levels of carbon dioxide on dark respiration and growth of plants. Plant Cell Environ. 1985, 8, 623-628. [CrossRef]

61. Gale, J. Evidence for essential maintenance respiration of leaves of Xanthium strumarium at high temperature. J. Exp. Bot. 1982, 33, 471-476. [CrossRef]

62. Cavagnaro, T.R.; Sokolow, S.K.; Jackson, L.E. Mycorrhizal effects on growth and nutrition of tomato under elevated atmospheric carbon dioxide. Funct. Plant Biol. 2007, 34, 730-736. [CrossRef]

63. Jakobsen, I.; Rosendahl, L. Carbon flow into soil and external hyphae from roots of mycorrhizal cucumber plants. New Phytol. 1990, 115, 77-83. [CrossRef]

64. Kaschuk, G.; Kuyper, T.W.; Leffelaar, P.A.; Hungria, M.; Giller, K.E. Are the rates of photosynthesis stimulated by the carbon sink strength of rhizobial and arbuscular mycorrhizal symbioses? Soil Biol. Biochem. 2009, 41, 1233-1244. [CrossRef]

65. Zhu, X.C.; Song, F.B.; Liu, S.Q.; Liu, F.L. Arbuscular mycorrhiza improve growth, nitrogen uptake, and nitrogen use efficiency in wheat grown under elevated $\mathrm{CO}_{2}$. Mycorrhiza 2016, 26, 133-140. [CrossRef] [PubMed]

66. Jauregui, I.; Aroca, R.; Garnica, M.; Zamarreno, A.M.; Garcia-Mina, J.M.; Serret, M.D.; Parry, M.; Irigoyen, J.J.; Aranjuelo, I. Nitrogen assimilation and transpiration: Key processes conditioning responsiveness of wheat to elevated $\left[\mathrm{CO}_{2}\right]$ and temperature. Physiol. Plantarum 2015, 155, 338-354. [CrossRef]

67. Liao, J.; Hou, Z.; Wang, G. Effects of elevated $\mathrm{CO}_{2}$ and drought on chemical composition and decomposition of spring wheat (Triticum aestivum). Funct Plant Biol. 2002, 29, 891-897. [CrossRef]

68. Taub, D.R.; Wang, X. Why are nitrogen concentrations in plant tissues lower under elevated $\mathrm{CO}_{2}$ ? A critical examination of the hypotheses. J. Integr. Plant Biol. 2008, 50, 1365-1374. [CrossRef]

69. McGrath, J.M.; Lobell, D.B. Reduction of transpiration and altered nutrient allocation contribute to nutrient decline of crops grown in elevated $\mathrm{CO}_{2}$ concentrations. Plant Cell Environ. 2013, 36, 697-705. [CrossRef] [PubMed]

70. Del Pozo, A.; Pérez, P.; Gutiérrez, D.; Alonso, A.; Morcuende, R.; Martínez-Carrasco, R. Gas exchange acclimation to elevated $\mathrm{CO}_{2}$ in upper-sunlit and lower-shaded canopy leaves in relation to nitrogen acquisition and partitioning in wheat grown in field chambers. Environ. Exp. Bot. 2007, 59, 371-380. [CrossRef]

71. Drake, B.G.; Gonzàlez-Meler, M.A.; Long, S.P. More efficient plants a consequence of rising atmospheric $\mathrm{CO}_{2}$ ? Ann. Rev. Plant Physiol. Plant Mol. Biol. 1997, 48, 609-639. [CrossRef]

72. Bloom, A.J.; Burger, M.; Asensio, J.S.R.; Cousins, A.B. Carbon dioxide enrichment inhibits nitrate assimilation in wheat and Arabidopsis. Science 2010, 328, 899-903. [CrossRef]

73. Asensio, J.S.; Rachmilevitch, S.; Bloom, A.J. Responses of Arabidopsis and wheat to rising $\mathrm{CO}_{2}$ depend on nitrogen source and nighttime $\mathrm{CO}_{2}$ levels. Plant Physiol. 2015, 168, 156-163. [CrossRef]

74. Staddon, P.L.; Jakobsen, I.; Blum, H. Nitrogen input mediates the effect of free-air $\mathrm{CO}_{2}$ enrichment on mycorrhizal fungal abundance. Glob. Chang. Biol. 2004, 10, 1678-1688. [CrossRef]

75. Jin, J.; Tang, C.; Armstrong, R.; Butterly, C.; Sale, P. Elevated $\mathrm{CO}_{2}$ temporally enhances phosphorus immobilization in the rhizosphere of wheat and chickpea. Plant Soil 2013, 368, 315-328. [CrossRef]

76. Swarup, A.; Patra, A.; Chandrakala, J.; Manjaiah, K. Effect of elevated $\mathrm{CO}_{2}$ and temperature on phosphorus efficiency of wheat grown in an Inceptisol of subtropical India. Plant Soil Environ. 2012, 58, 230-235.

77. Jongen, M.; Fay, P.; Jones, M.B. Effects of elevated carbon dioxide and arbuscular mycorrhizal infection on Trifolium Repens. New Phytol. 1996, 132, 413-423. [CrossRef] [PubMed] 
78. Jin, J.; Tang, C.; Sale, P. The impact of elevated carbon dioxide on the phosphorus nutrition of plants: A review. Ann. Appl. Biol. 2015, 116, 987-999. [CrossRef] [PubMed]

79. Brown, L.K.; George, T.S.; Barrett, G.E.; Hubbard, S.F.; White, P.J. Interactions between root hair length and arbuscular mycorrhizal colonisation in phosphorus deficient barley (Hordeum vulgare). Plant Soil 2013, 372, 195-205. [CrossRef]

80. Haling, R.E.; Brown, L.K.; Bengough, A.G.; Young, I.M.; Hallett, P.D.; White, P.J.; George, T.S. Root hairs improve root penetration, root-soil contact, and phosphorus acquisition in soils of different strength. J. Exp. Bot. 2013, 64, 3711-3721. [CrossRef] [PubMed]

81. Alberton, O.; Kuyper, T.W.; Gorissen, A. Taking mycocentrism seriously: Mycorrhizal fungal and plant responses to elevated $\mathrm{CO}_{2}$. New Phytol. 2005, 167, 859-868. [CrossRef] [PubMed]

82. Das, S.; Bhattacharyya, P.; Adhya, T. Interaction effects of elevated $\mathrm{CO}_{2}$ and temperature on microbial biomass and enzyme activities in tropical rice soils. Environ. Monit. Assess 2011, 182, 555-569. [CrossRef]

83. Kelley, A.M.; Fay, P.A.; Polley, H.W.; Gill, R.A.; Jackson, R.B. Atmospheric $\mathrm{CO}_{2}$ and soil extracellular enzyme activity: A meta-analysis and $\mathrm{CO}_{2}$ gradient experiment. Ecosphere 2011, 2, art96. [CrossRef] 